\title{
Europa w kryzysie: perspektywy gospodarcze Unii Europejskiej do 2020 roku w kontekście problemów rozwojowych państw grupy PIIGS
}

W celu przeciwdziałania negatywnym tendencjom rozwojowym, spadkowi konkurencyjności gospodarczej w Unii Europejskiej i wielu problemom społecznym z rosnącym bezrobociem na czele, Komisja Europejska na początku 2010 roku zaproponowała państwom członkowskim Unii przyjęcie programu (strategii) „Europa 2020”. Z założenia stanowić ma on wizję nowoczesnej, społecznej gospodarki rynkowej dla Europy w XXI wieku. Strategia „Europa 2020” stanowi plan działania, który UE oraz jej państwa członkowskie przyjęł, aby pomóc Europie wyjść ze światowego kryzysu finansowego silniejszq wewnętrznie i na arenie międzynarodowej. Wydobycie Europy z kryzysu, jak stwierdziła Komisja Europejska, wymaga skoordynowanego i wszechstronnego programu reform, obejmującego konsolidację budżetową, przywrócenie stabilnych warunków makroekonomicznych, koncentrację środków polityki budżetowej oraz sprawne uzdrowienie sektora finansowego w celu wejścia na drogę naprawy gospodarczej. Kolejny priorytet to szybkie ograniczenie bezrobocia oraz wdrożenie skutecznych reform na rynku pracy. Tego typu polityka korzystnie wpłynie również na konsolidację budżetową, generując wyższe wpływy z podatków oraz sprzyjać będzie obniżeniu wydatków publicznych na transfery socjalne. Pomoże też ograniczyć ryzyko przyszłej nierównowagi makroekonomicznej. Skuteczne reformy objąć mają też poprawę funkcjonowania rynku produktów, stymulowanie innowacji oraz poprawę warunków ramowych dla przedsiębiorców w Europie. Najpilniejszym zadaniem jest jednak zmniejszenie bardzo wysokich pułapów zadłużenia, likwidacja zakłóceń na rynkach finansowych oraz niskiego wzrostu gospodarczego obserwowanego w niektórych państwach członkowskich Unii. Pozwolić to ma na przyciągnięcie większej liczby zagranicznych inwestycji prywatnych, które $\mathrm{z}$ kolei poprawią sytuację w zakresie ich stanu finansów publicznych. Reformy strukturalne powinny przynieść znaczne korzyści nawet w perspektywie krótkoterminowej. Będą nimi przede wszystkim zyski w postaci wzrostu produkcji i zatrudnienia ${ }^{1}$.

Strategia „Europa 2020” obejmuje trzy wzajemnie ze sobą powiązane priorytety:

— rozwój inteligentny: rozwój gospodarki opartej na wiedzy i innowacji;

— rozwój zrównoważony: wspieranie gospodarki efektywniej korzystającej z zasobów, bardziej przyjaznej środowisku i bardziej konkurencyjnej;

- rozwój sprzyjajacy właczeniu społecznemu: wspieranie gospodarki o wysokim poziomie zatrudnienia, zapewniającej spójność społeczną i terytorialną.

\footnotetext{
${ }^{1}$ Roczne sprawozdanie gospodarcze. Załacznik 1: Sprawozdanie z postępu prac dotyczacych strategii „Europa 2020”, Komisja Europejska, Bruksela, dnia 12.1.2011, KOM(2011) 11 wersja ostateczna.
} 
Komisja Europejska zaproponowała jednocześnie wytyczenie kilku nadrzędnych, wymiernych celów UE zapewniających realizację następujących priorytetów:

— wskaźnik zatrudnienia osób w wieku 20-64 lat powinien wynosić 75\%;

— na inwestycje w badania i rozwój $(\mathrm{B}+\mathrm{R})$ należy przeznaczać 3\% PKB Unii;

— należy osiagnąć cele pakietu klimatyczno-energetycznego „20/20/20” (w tym ograniczenie emisji dwutlenku węgla nawet o $30 \%$, jeśli pozwolą na to warunki);

- liczbę osób przedwcześnie kończących naukę szkolną należy ograniczyć do $10 \%$, a co najmniej 40\% osób z młodego pokolenia powinno zdobywać wyższe wykształcenie;

— liczbę osób zagrożonych ubóstwem należy zmniejszyć o $20 \mathrm{mln}$.

Powyższe cele szczegółowe wpisywać mają się w realizację trzech ogólnych priorytetów, tzn. rozwoju inteligentnego, zrównoważonego i sprzyjajacego właczeniu społecznemu ${ }^{2}$.

Program ,Europa 2020”, pomimo różnych kontrowersji związanych z jego priorytetami w łonie samej Unii, ma szanse być realizowany tylko i wyłącznie w sytuacji ustabilizowanego rozwoju państw strefy euro - ,gospodarczego rdzenia” Wspólnot. Występuje tu klasyczne sprzężenie zwrotne. Strategia może pomóc wyjść gospodarkom unijnym z kryzysu, a gospodarki te poprzez wdrażane reformy warunkują sukces strategii. Na ocenę korzyści związanych z uczestnictwem w projekcie wspólnej waluty europejskiej i w ogóle prawidłowego przebiegu procesów integracyjnych poważnie wpłynął światowy kryzys gospodarczy z lat 2008-2009 (zwany też w niektórych analizach „2008+”, licząc od dnia 15 września 2008 roku - spektakularnego bankructwa amerykańskiego banku inwestycyjnego Lehman Brothers do dziś), skutkujący w Unii Europejskiej recesją gospodarczą. Oprócz Niemiec, Wielkiej Brytanii i Łotwy, kryzys szczególnie mocno dotknął państwa tzw. grupy PIIGS (Portugal, Italy, Ireland, Greece, Spain).

W kontekście skutków globalnego kryzysu gospodarczego Komisja Europejska w 2010 roku podkreśliła że: ...obecny kryzys gospodarczy nie miat w czasach naszego pokolenia precedensu. Nieprzerwany postęp pod względem wzrostu gospodarczego i rosnacego zatrudnienia, towarzyszacy nam przez ostatnie dziesięciolecie, zostat zaprzepaszczony - PKB skurczyt się w 2009 r. o 4\%, produkcja przemystowa spadta do poziomu z lat 90-tych, a 23 miliony osób (czyli 10\% aktywnej zawodowo ludności UE) jest bez pracy. Kryzys byt szokiem dla milionów obywateli i ujawnit pewne fundamentalne słabości naszej gospodarki. Bardzo ucierpiały nasze finanse publiczne - deficyt budżetowy wynosi średnio 7\% PKB, a poziom dtugu przekracza $80 \%$ PKB. Dwa lata kryzysu przekreślity 20 lat konsolidacji budżetowej. Kryzys zmniejszyt nasz potencjat wzrostu o połowę. Wiele projektów inwestycyjnych, talentów i pomystów najprawdopodobniej przepadnie z powodu niepewności, słabego popytu i braku finansowania. Średnia stopa wzrostu $w$ Europie była strukturalnie niższa $w$ porównaniu z naszymi największymi partnerami gospodarczymi, głównie z uwagi na różnice w poziomach wydajności, rosnqce w ciagu ostatniego dziesięciolecia. Wynika to $w$ dużym stopniu z różnic w strukturach biznesowych, niższego poziomu inwestycji $w$ działalność badawczo-rozwojowa i innowacje, niewystarczajacego wykorzystania technologii informacyjno-komunikacyjnych, niechęci części naszych społeczeństw do wprowadzania innowacji, trudności $w$ dostępie do rynku i mniej dynamicznego otoczenia biznesu. Mimo postępów, wskaźniki zatrudnienia

\footnotetext{
${ }^{2}$ Komunikat Komisji, Europa 2020. Strategia na rzecz inteligentnego i zrównoważonego rozwoju sprzyjajacego właczeniu społecznemu, Bruksela, 3.3.2010, KOM(2010) 2020 wersja ostateczna. Szerzej na temat założeń strategii „Europa 2020” zob.: M. Walkowski, Główne wyzwania rozwojowe Unii Europejskiej w XXI wieku w kontekście założeń i realizacji Programu Europa 2020, w: Globalny i regionalny handel i inwestycje, red. nauk. J. Rymarczyk, B. Skulska, W. Michalczyk, Wrocław 2010.
} 
w Europie - średnio 69\% dla osób w wieku 20-64 lat-sq wciqż znacznie niższe niż w innych częściach świata. Pracuje tylko 63\% kobiet, podczas gdy zatrudnienie mężczyzn wynosi 76\%. Spośród osób starszych (osoby w wieku 55-64 lat) zatrudnionych jest 46\% - dla porównania, w Stanach Zjednoczonych i Japonii wskaźnik ten wynosi 62\%. Ponadto Europejczycy pracuja średnio 10\% czasu mniej niż pracownicy w USA lub Japonii. Spoleczeństwa starzeja się coraz szybciej. Wraz z odchodzeniem na emeryturę pokolenia wyżu demograficznego liczba osób aktywnych zawodowo zacznie się w UE zmniejszać poczqwszy od 2013/2014 r. Liczba osób $w$ wieku powyżej 60 lat rośnie dziś w tempie dwa razy szybszym niż przed rokiem 2007, tj. o ok. 2 mln osób rocznie - wcześniej byt to 1 mln rocznie. Mniejsza liczba ludności czynnej zawodowo $i$ wzrost liczby emerytów będzie dodatkowym obciażeniem dla naszych systemów opieki społecznej ${ }^{3}$.

Szczególne problemy gospodarcze przeżywa aktualnie grupa państw określana wymienionym już akronimem „PIIGS” (Portugal, Italy, Ireland, Greece, Spain). Są to gospodarki objęte unijną procedurą nadmiernego deficytu (odpowiednio: 9,4\%, 5,3\%, 14,3\%, 13,6\%, $11,2 \%$ w 2009 roku), z ogromnym w przypadku Włoch i Grecji długiem publicznym w relacji do PKB (odpowiednio: 76,8\%, 115,8\%, 64\%, 115,1\%, 53,3\%).

W przypadku państw zaliczanych do tej grupy, których ratingi wiarygodności kredytowej (np. Fitch Rating, Moody’s, Standard\&Poors) regularnie spadają, kryzys nie tyle jednak spowodował co wzmógł wcześniejsze problemy gospodarcze i finansowe. Dotyczy to szczególnie Grecji, Irlandii i Portugalii. Wynikają one bowiem z wieloletniego braku równowagi w sferze finansów publicznych, z tytułu prowadzenia przez lata nieodpowiedzialnej polityki makroekonomicznej i finansowej, skutkującej nadmiernymi deficytami budżetowymi i ogromnym długiem publicznym. Regularnie też i co gorsze bez żadnych konsekwencji politycznych i finansowych, państwa grupy PIIGS łamały kryteria konwergencji z Maastricht, co traktować należy jako ewidentny, praktyczny mankament funkcjonowania strefy euro. Symptomatyczny przy tym wydaje się przykład Grecji, z ponad 13 proc. deficytem budżetowym i ponad 120 proc. długiem publicznym w 2010 roku. Grecja wytwarza co prawda zaledwie 3 proc. DNB strefy euro, ale wysoki poziom współzależności ekonomicznej i finansowej w Unii Europejskiej powoduje, że potencjalne bankructwo gospodarki greckiej odbiłoby się bardzo negatywnie na kondycji gospodarczej pozostałych państw regionu śródziemnomorskiego oraz Francji, Niemiec, a nawet pozaunijnej Szwajcarii (tzw. efekt domina). Wartość wierzytelności w postaci greckich obligacji i udzielonych kredytów jest bowiem ogromna, liczona w dziesiątkach miliardów euro, a największą ekspozycję na grecki dług mają właśnie banki francuskie, niemieckie i szwajcarskie. Grecja wymagała więc pilnej i znaczącej pomocy finansowej. Sama też musiała wdrażać radykalny program oszczędnościowy i to bez względu na duży opór społeczny i wyraźną niechęć skorych do strajków i protestów Greków do tzw. ,zaciskania pasa”. Grecja musi też jako prawarunek uzyskania pomocy finansowej z UE i innych instytucji finansowych zacząć spłacać swe zagraniczne zobowiązania dłużne.

W Europie istnieje poważna obawa przed tym, aby kryzys finansów publicznych w małej gospodarce greckiej, w wyniku ścisłych powiązań handlowych i finansowych z innymi kraja-

\footnotetext{
${ }^{3}$ Por. Komunikat Komisji do Parlamentu Europejskiego, Rady, Europejskiego Komitetu Ekonomiczno-Społecznego i Komitetu Regionów, W kierunku Aktu o jednolitym rynku. W stronę społecznej gospodarki rynkowej o wysokiej konkurencyjności. 50 propozycji na rzecz wspólnej poprawy rynku pracy, przedsiębiorczości i wymiany, Bruksela, dnia 27.10.2010, KOM(2010) 608, wersja ostateczna. Zob. również: The euro zone. The Jekyll and Hyde economy, „The Economist”, May $13^{\text {th }} 2011$; Europe's Europe crisis. How long can this go on?, „The Economist” May $13^{\text {th }}$ 2011; The euro zone. A terminal crisis?, „The Economist”, Jun $21^{\text {st }} 2010$.
} 
mi regionu śródziemnomorskiego (nieco żartobliwie nazywanego w tabloidach „Club Med. Region”) oraz największymi gospodarkami europejskimi, z Niemcami i Francją na czele nie rozlał się i nie zagroził istnieniu całej strefy euro. Obawy zainfekowania „greckim wirusem” dotyczą przy tym nie tylko Portugalii, której ratingi wiarygodności kredytowej spadają, ale i Hiszpanii - gospodarki czterokrotnie większej od Grecji, z PKB rzędu 1,2 bln euro (2009 rok) i niemal 12\% udziałem w tworzeniu zagregowanego PKB całej strefy euro. Bez głębokich reform finansów publicznych (m.in. podwyższenie wieku emerytalnego, cięcia nieefektywnych wydatków socjalnych, ograniczenia zatrudnienia w administracji publicznej, podwyżki podatków, zamrożenie inwestycji publicznych, ograniczenie zarobków w sferze budżetowej, uelastycznienie rynku pracy z renegocjacją umów zbiorowych zawartych ze związkami zawodowymi włącznie) nie uda się Hiszpanii znacząco ograniczyć ponad $4 \mathrm{mln}$ bezrobocia, osiagnąć choćby niewielki wzrost gospodarczy w latach 2010-2012 i nie wejść - na wzór Grecji - w spiralę zadłużenia. Hiszpanii, jak i pozostałym państwom grupy celowo i dwuznacznie nazywanej PIIGS (w brzmieniu: ŚWINIE, choć w swobodnym przekładzie na język polski lepiej brzmiałoby tu określenie CZARNE OWCE), pomóc w naprawie sytuacji społeczno-gospodarczej (pomóc, a nie wyręczyć!) miał specjalny pakiet pomocy finansowej, zatwierdzony w maju 2010 roku przez ministrów finansów Unii Europejskiej, czyli Europejski Mechanizm Stabilizacji Finansowej - EMSF (European Financial Stability - Facitity - EFSF ). Zakłada on znaczące wsparcie, realnie lub potencjalnie zagrożonych kryzysem finansowym państw „euro area”, w postaci kredytów, gwarancji kredytowych i pożyczek w wysokości 750 mld euro. Sumę 60 mld euro ma wyasygnować na ten cel Komisja Europejska, 440 mld euro - państwa członkowskie strefy, a 250 mld pochodzić ma z MFW. Europejski Bank Centralny będzie też mógł (co zresztą już w maju 2010 roku uczynił względem Grecji) skupować obligacje państw zagrożonych niewypłacalnością. Wsparcie tego typu traktowane jest jednak jako „ostatnia instancja”, w sytuacji gdy wszystkie inne formy pomocy się wyczerpią lub zawiodą. Kraj nim objęty zobowiązać musi się do radykalnych reform, odbudowujących zaufanie inwestorów w świecie do stanu swych finansów publicznych. Przyjęcie tak wynegocjowanego pakietu pomocy finansowej traktować należy przy tym nie tylko jako godzien uwagi przejaw solidarności społeczno-politycznej w UE (wyjątkiem i to niechlubnym jest Słowacja, która odmówiła wkładu własnego, jakby zapominając o korzyściach, jakie sama czerpie np. z funduszy spójnościowych), ale przede wszystkim jako obiektywną konieczność rozwojową, zapobiegającą w Europie tzw. ,, efektowi domina”, czyli destabilizacji gospodarczej całej zintegrowanej, współzależnej rozwojowo Europy. Bankructwo zadłużonych Grecji, Portugalii, Włoch, Hiszpanii czy Irlandii, groziłoby bowiem poważną destabilizacją finansową w Niemczech i Francji, największych gospodarkach europejskich - ,depozytariuszach” długów państw grupy PIIGS (banki komercyjne), trwałą recesją gospodarczą w Europie, a nawet - choć to raczej mało prawdopodobne - rozpadem strefy euro i całej idei integracji europejskiej ${ }^{4}$.

Europejski Mechanizm Stabilizacyjny - EMS (EFSM), mający wyraźnie niemiecki rodowód polityczny, będzie obowiązywał od czerwca 2013 roku, zastępując tymczasowy EMSF. Warunkiem otrzymania pomocy jest nie tylko wdrożenie drastycznego programu oszczędno-

\footnotetext{
${ }^{4}$ Szerzej zob.: www.efsf.europa.eu. Niektórzy ekonomiści, jak choćby znany z trafnych prognoz dotyczących nieuchronnego pojawienia się kryzysu finansowego w Stanach Zjednoczonych Nouriel Roubini, uważają że powołanie do życia EMSF jest trafnym posunięciem, ale możliwości finansowe instrumentu powinny być 4-5-krotnie większe. Jedynie suma rzędu 2-3 bln euro stwarzałaby szanse na skuteczne odsunięcie groźby potencjalnego bankructwa Włoch czy Hiszpanii.
} 
ściowego, ale także zobowiązanie danego państwa, że spłaci tę pożyczkę w ściśle wyznaczonym terminie. Decyzja o stworzeniu trwałego mechanizmu antykryzysowego ma być demonstracją jedności europejskiej, a także przekonania, że wspólna waluta euro ma sens i przyszłość. Po spodziewanej pozytywnej decyzji przywódców państw członkowskich UE natychmiast rozpocznie się procedura zmiany Traktatu lizbońskiego. Znajdą się tam dwa nowe akapity: Państwa członkowskie posługujace się euro moga zdecydować o stworzeniu mechanizmu stabilizacyjnego, jeśli okaże się niezbędny dla ochrony strefy euro jako całości. Udzielenie przewidzianej mechanizmem pomocy finansowej będzie obwarowane ostrymi warunkami. Zmiana w traktacie jest konieczna, bowiem obecnie wprost zabrania on ratowania państw strefy euro. Jego zapisy pochodzą bowiem z czasów, gdy takie bankructwo wydawało się wręcz nieprawdopodobne. Dlatego też w przypadku Grecji i Irlandii o pomocy z EMSF decydowano na bieżąco. Nowy zapis został tak sformułowany przez prawników, że nie tworzy nowych kompetencji Unii kosztem narodowej suwerenności i możliwe staje się zastosowanie procedury przyspieszonej. Na szczycie w marcu 2011 roku miała zostać formalnie podpisana

\section{Wykres 1. Stan finansów publicznych w państwach członkowskich Unii Europejskiej}

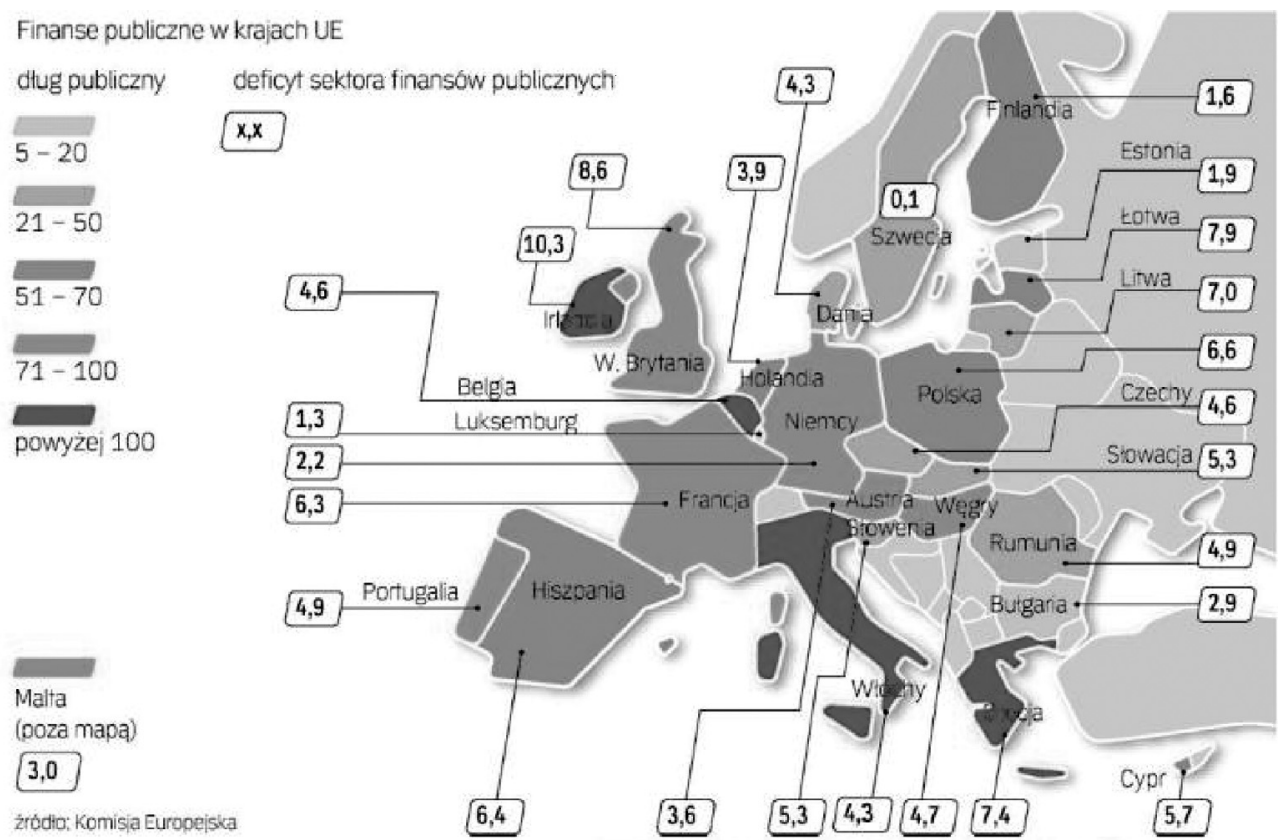

-POGRAZZZNA W KRYZYSIE FISKALNYM EUROPA MUSI OSZCZĘDZAC, ALE MAQDRZE

Źródło: Komisja Europejska.

zmiana w traktacie, a do końca 2012 roku nastąpić ratyfikacja we wszystkich 27 państwach członkowskich UE. Traktatowa poprawka weszłaby w życie 1 stycznia $2013 \mathrm{roku}^{5}$.

5 A. Słojewska, Lek na kryzys strefy euro, „Rzeczpospolita”, 17 grudnia 2010 r.

Europejski Mechanizm Stabilizacyjny (EMS, ang. EFSM), opierać się będzie na kilku podstawowych zasadach: 
Wykres 2. Pochodzenie (sources) oraz przeznaczenie (allocation) środków finansowych Europejskiego Mechanizmu Stabilizacji Finansowej (EFSF) i Międzynarodowego Funduszu Walutowego (IMF) - w mld euro, kwiecień 2011 r.

\section{European bail-out funds}

Sources, Ebn, April 7th 2011

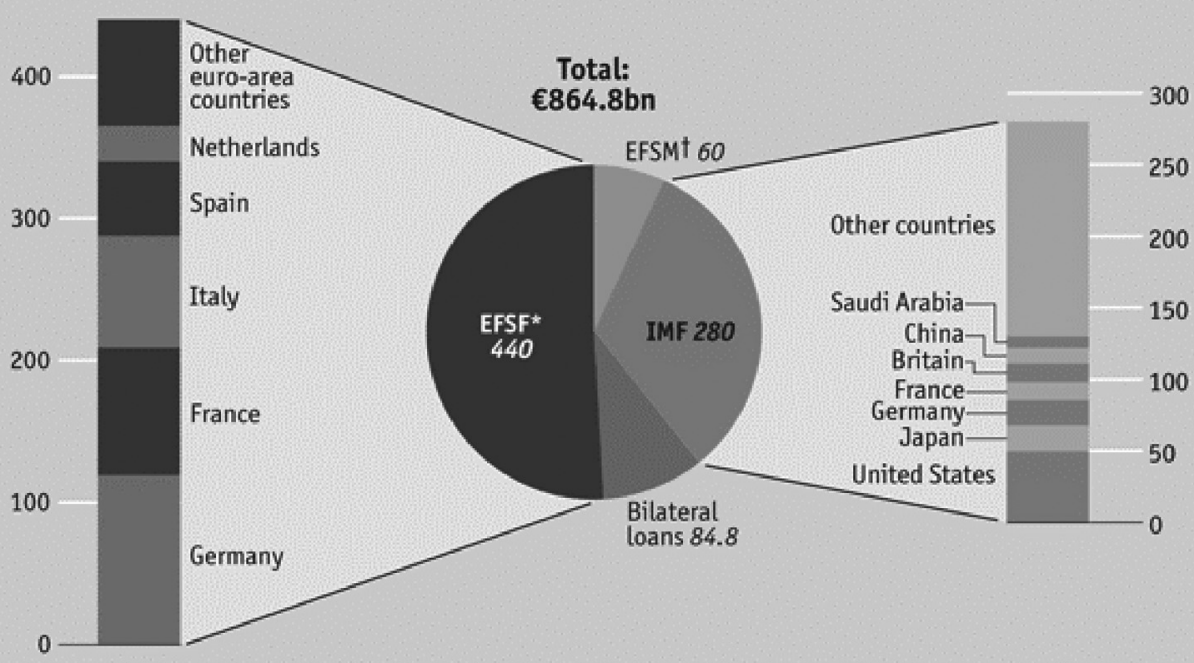

Allocation, Ebn, April 7th 2011

Total:

€864.8bn

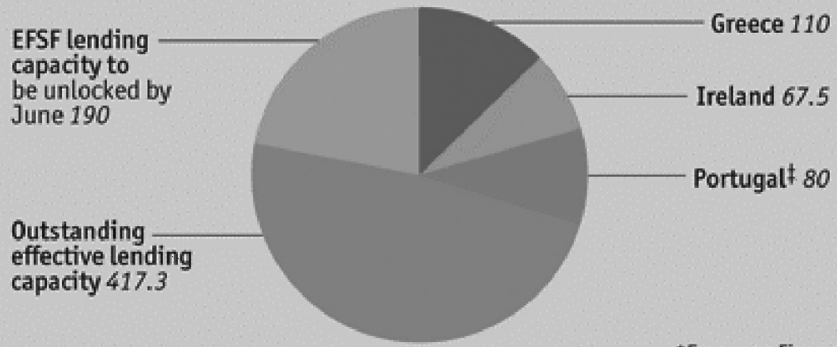

"European Financial Stability Facility

Sources: EFSF; European Commission; IMF; The Economist

†European Financial Stabilisation Mechanism fEstimate

Źródło: EFSF, Komisja Europejska, MFW, „The Economist”.

— pożyczki z EMS będą uprzywilejowane i będą spłacane w drugiej kolejności, po MFW;

- warunkiem pożyczki będzie surowy program dostosowania gospodarczego i fiskalnego uzgodniony z KE, MFW i Europejskim Bankiem Centralnym;

— decyzja o udzieleniu pożyczki będzie podejmowana jednomyślnie przez ministrów finansów państw strefy euro;

— udział inwestorów prywatnych w programie ratowania państwa będzie zgodny z zasadami MFW;

— w razie problemów z wypłacalnością państwo musi przeprowadzić negocjacje w sprawie restrukturyzacji długu na wzór tych prowadzonych przez MFW;

— od czerwca 2013 roku wszystkie obligacje skarbowe w strefie euro będą zawierały klauzule CAC (collective action clause) pozwalające większości dłużników na uzgodnienie warunków restrukturyzacji długu;

- ocenę mechanizmu przewidziano w 2016 roku. 
Oczywiście problem zadłużenia w dobie globalnego kryzysu gospodarczego i finansowego nie jest tylko i wyłącznie problemem strefy euro. Jest to poważny, globalny problem współczesnego rozwoju społeczno-gospodarczego. Zdaniem analityków OECD na świecie są obecnie trzy państwa, w przypadku których istnieje ponad 50-procentowe ryzyko, że któregoś dnia ujawnią swoją niezdolność do obsługi zadłużenia. Najbardziej zagrożona jest pod tym względem Ukraina (57 procent), za nią Argentyna (53 procent) i Wenezuela (51 procent). I to mimo tego, że ich dług, jak na aktualne standardy, wcale nie jest wysoki - na Ukrainie wynosi 33 procent $\mathrm{PKB}, \mathrm{w}$ Wenezueli -27 procent $\mathrm{PKB}, \mathrm{w}$ Argentynie - 22 procent. Polski dług publiczny balansuje na granicy 55 procent PKB. Z kolei w opinii ekonomistów Oxford Economics inwestorzy obawiają się, że niemożność obsługi swojego zadłużenia ogłoszą Irlandia, Portugalia oraz Hiszpania, chociaż ich zdaniem całą strefę euro raczej czeka bardzo powolny powrót do ożywienia gospodarczego, a nie kontrolowane bankructwo. Takiemu scenariuszo-

Wykres 3. Najbardziej zadłużone państwa świata wg OECD

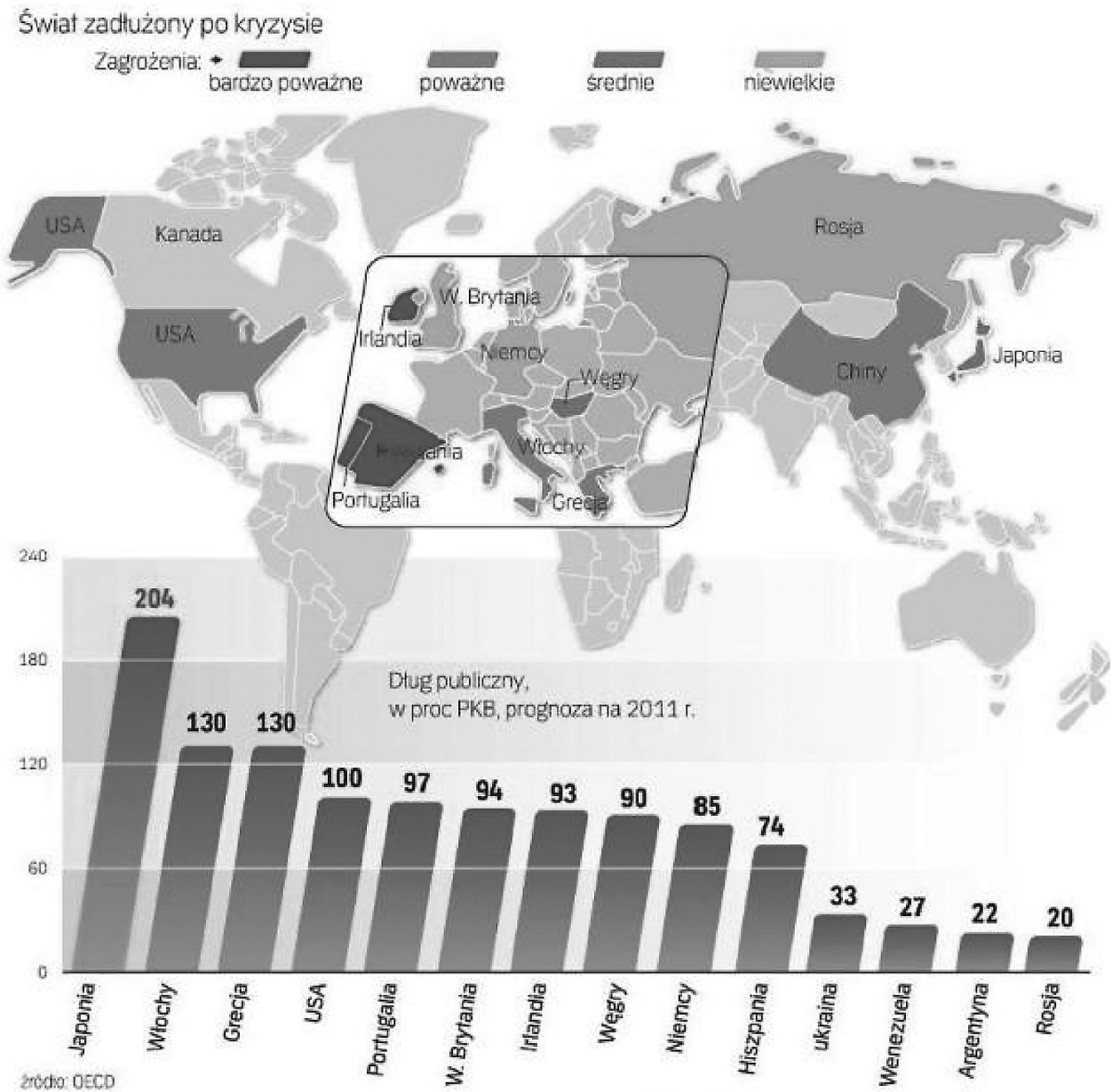

-STREFA EURO NAJWIĘKSZYM ZAGROZENIEM DLA SWWIATOWYCH FINANSOW

Źródlo: Dane OECD. 
wi ten think tank daje 45 procent prawdopodobieństwa ${ }^{6}$. Eksperci Oxford Economics nie wykluczają, że w Grecji może dojść do tzw. „kontrolowanej niewypłacalności”. Kanclerz Niemiec Angela Merkel podkreśliła, że cała strefa euro z powodu sytuacji w grupie PIIGS znalazła się w wyjątkowo trudnej sytuacji. Ewentualna restrukturyzacja długu Grecji, Irlandii, Portugalii, czy Hiszpanii spowodowałaby negatywny efekt w USA, Japonii, Wielkiej Brytanii i tych państwach, w których dług publiczny jest bardzo wysoki. Zdaniem ekonomistów, gdyby doszło zaś do konieczności ratowania gospodarki Hiszpanii, niezbędna byłaby kwota co najmniej 500 mld euro, co w zasadzie wyczerpałoby unijne fundusze pochodzące z $\mathrm{EMSF}^{7}$. Analitycy z londyńskiego Capital Economics byli z kolei zdania, że $z$ unijnej i międzynarodowej pomocy finansowej (UE/EBC/MFW) będzie zmuszona skorzystać też Portugalia, refinansująca swoje zadłużenie. Wzrost gospodarczy w Portugalii przez ostatnie dziesięć lat oscylował wokół zaledwie 1 procenta PKB, a kolejne rządy nazbyt szczodrze finansowały rozmaite programy socjalne z pożyczonych na światowym rynku pieniędzy. Aktualnie finansowanie długu bardzo podrożało, bowiem wyraźnie wzrosło jego oprocentowanie. Według analizy Capital Economics całkowite zadłużenie Portugalii, tj. państwa, przedsiębiorstw państwowych, korporacji prywatnych oraz gospodarstw domowych - wynosi aktualnie około 160 mld euro. Zdaniem Eurostatu to aż 97 procent PKB $^{8}$.

\section{GRECJA}

Zgodnie z przedstawionym ma początku października 2010 roku projektem deficyt finansów publicznych w 2011 roku w Grecji wyniesie 7 procent PKB. Grecja zdecydowała się więc na bardziej znaczące ograniczenie deficytu niż określają to wymagania stawiane przez Międzynarodowy Fundusz Walutowy oraz Unię Europejską, według których powinien on wynieść mniej niż 7,8 procenta PKB. Był to jeden z głównych warunków, od których spełnienia były uzależnione losy 110 mld euro pomocy finansowej dla Grecji wygospodarowanej przez te instytucje. Projekt reform przewiduje, że wydatki budżetowe spadną o prawie 6 procent, do 67,5 mld euro. Przychody wzrosną zaś o niemal 7 procent do poziomu 56,3 mld euro. Grecja zrobiła pewne postępy, jeśli chodzi o reformowanie finansów publicznych. Przez pierwszych osiem miesięcy 2010 roku deficyt zmniejszył się o 32 procenty w porównaniu z takim samym okresem 2009 roku. O ile w 2009 roku wyniósł aż 13,6 procenta PKB, to w 2010 roku miał spaść poniżej 7,8 procenta PKB. Stosunkowo szybkie tempo konsolidacji fiskalnej to głównie efekt cięć wydatków budżetowych. Nie są one jednak w pełni satysfakcjonujące. Znacznie gorzej idzie rządowi greckiemu ze zwiększaniem wpływów do budżetu. Do końca sierpnia 2010 roku wzrosły one jedynie o 3,4 procent (w skali rocznej), podczas gdy

${ }^{6}$ D. Walewska, Kryzys jeszcze się nie skończyt, „Rzeczpospolita”, 24 listopada $2010 \mathrm{r}$.

${ }^{7}$ aft, Dlug blisko 55 proc. PKB, „Rzeczpospolita”, 24 listopada 2010 r.

${ }^{8}$ Charlemagne. Decision time. Germany continues to dither over how best to rescue the euro, , The Economist", May $12^{\text {th }}$ 2011; d.w., Portugalia pod presja, „Rzeczpospolita”, 24 listopada 2010 r. Zob. również: Europejski Bank Centralny podwyższa kapitał, ,Rzeczpospolita”, 17 grudnia 2010 r. Europejski Bank Centralny w grudniu 2010 roku ogłosił, że podwyższy kapitał o 5 mld euro do sumy 10,76 mld euro. Pieniądze te będą pochodziły od 16 banków centralnych państw strefy euro oraz kilku instytucji tego typu z państw Unii Europejskiej nie należących do strefy. Narodowy Bank Polski zwiększy swe udziały w EBC o 244,77 mln euro do sumy ogółem 526,78 mln euro. Podwyższenie kapitału ma zabezpieczyć EBC przed ewentualnymi stratami na nisko notowanych w ratingach obligacjach państw z peryferii strefy euro skupowanych przez tę instytucję już od maja 2010 roku. Jak do tej pory ECB przeznaczył na ten program 72 mld euro. 
rząd prognozował wzrost rzędu 13,7 procent. Greckie władze spodziewają się, że w 2011 roku zwiększanie przychodów budżetowych poprawi się, gdyż wejdą w życie uchwalone podwyżki podatków. Problemem jest jednak to, że Grecy nagminnie uchylają się od ich płacenia (mocno rozbudowana szara strefa, wg niektórych szacunków sięgająca 25 proc. PKB), a urzędy skarbowe wciąż nie poprawiły ich bardzo słabej ściągalności ${ }^{9}$.

W październiku 2010 roku duże poruszenie w Grecji wywołały wypowiedzi Jean-Claude Junckera. Podczas pobytu w Waszyngtonie stwierdził on, że fatalna kondycja fiskalna i wielkie finansowe problemy Grecji były znane w Unii od lat. Było jasne, że prędzej czy później Grecy będq musieli się zmierzyć z tym problemem, wiedzieliśmy, że to się zdarzy - powiedział premier Luksemburga stojący na czele tzw. eurogrupy. Jak dodał J. C. Juncker, Unia Europejska nie zrobiła wcześniej nic, aby greckiemu kryzysowi zaradzić, oprócz tego że on sam próbował przed nimi przestrzec jednego z greckich premierów - Costasa Simitisa (czemu ten zresztą kategorycznie zaprzecza) ${ }^{10}$. Generalnie znaczna część społeczeństwa greckiego za obecny stan swej gospodarki winą obarcza wszystkich, z własnymi politykami i instytucjami UE na czele, tylko nie siebie. Pojawiają się kompletnie (z punktu widzenia interesu greckiego, ale już niekoniecznie europejskiego) surrealistyczne pomysły wyjścia Grecji ze strefy euro i powrotu do drachmy (w domyśle: powrotu do czasów stabilizacji i dobrobytu). W odpowiedzi na tego typu argumentację grupa osiemnastu znanych i cenionych greckich ekonomistów przedstawiała symulację dotyczącą tego co hipotetycznie stałoby się gdyby Grecja w ogóle przestała spłacać długi, przestała dążyć do równowagi w sferze finansów publicznych i uzdrowienia administracji publicznej, zaprzestała walki z wszechobecną szarą strefą i zaczęła ewoluować w kierunku autarkii gospodarczej poza strefą euro. Wynikało z niej, że niemal natychmiast stawki płac w sektorze publicznym drastycznie spadłyby, wiele banków upadłoby, a powrót do drachmy oznaczałby szalejącą hiperinflację. Theodoros Pangolos deputowany do greckiego parlamentu bez ogródek stwierdził, że powrót do drachmy to w istocie tyle co panika wśród drobnych inwestorów i depozytariuszy wycofujacych swe lokaty z banków, puste sklepy, niepokoje społeczne na niespotykanq dotad skale i grecka armia na ulicach ${ }^{11}$.

Wydaje się, że jeśli sami Grecy w wielu wymiarach swego życia i pracy nie dokonają gruntownych przewartościowań i zauważalnej metamorfozy scenariusz ten może się ziścić. Grecy muszą się pogodzić z faktem, że tak rozbudowanych i kosztownych przywilejów socjalnych już nigdy nie będzie, że trzeba dłużej i efektywniej pracować, że trzeba legalnie odprowadzać podatki, że trzeba likwidować korupcjogenny i powszechny w tym kraju system koncesyjny (statystyczny Grek wg Transparency International na łapówki przeznaczał 1300 euro rocznie!), wreszcie zmniejszać wyjątkowo duże nawet jak na Europę wpływy związków zawodowych i sektora państwowego jako takiego. Grecy poproszeni przez zagranicznych turystów o paragon fiskalny zazwyczaj „nagle” przestają rozumieć w języku angielskim, a zbiurokratyzowane i skorumpowane urzędy z reguły pracują nie dłużej niż do 14.00. Jak obliczono, około 50 tysięcy zmarłych jeszcze kilka lat po swej śmierci pobierało w tym kraju emerytury (a raczej członkowie ich rodzin) i nikt z urzędników tego nie kontrolował. Greckie zasiłki dla bezrobotnych, były przed kryzysem „2008+” długotrwałe i relatywnie wysokie,

\footnotetext{
${ }^{9}$ H. Kozieł, Grecja ostro tnie wydatki, „Rzeczpospolita”, 5 października 2010 r.

${ }^{10}$ M. Piotrkowski, O greckim kryzysie wiedzieli wszyscy, tylko nie Grecja, „Gazeta Wyborcza”, 12 października $2010 \mathrm{r}$.

${ }^{11}$ Greece's agony. What have we become, (Europe), „The Economist”, July $2^{\text {nd }} 2011$. Zob. również: Greece's debt crisis. Trichet the intransigent. The European Central Bank's refusal to consider a restructuring of Greek debt could wreck the euro zone, ,The Economist”, May $12^{\text {th }} 2011$.
} 
skutecznie zniechęcając część społeczeństwa do pracy. W bardzo wielu profesjach istniała możliwość przejścia na emeryturę już po 15-20 latach. Na porządku dziennym jest w Grecji nepotyzm, czyli zatrudnianie w oparciu o więzy krwi a nie kompetencje, a w przedsiębiorstwach państwowych, nawet najsłabszy pracownik (często dla bezpieczeństwa też związkowiec) był praktycznie nieusuwalny do czasu wejścia w wiek emerytalny. We współczesnym świecie zrelatywizowanych wartości silne przywiązanie Greków do więzów rodzinnych uznać należy za godne szacunku. Niekoniecznie jednak jest ono wskazane w sferze zatrudnienia, awansu czy obiektywnej oceny pracownika. Powszechna niechęć do odprowadzania podatków powoduje, że Grecję, słusznie nazywa się biednym krajem bogatych ludzi. Inaczej mówiąc w budżecie chronicznie brakuje pieniędzy, ale dobrych i drogich samochodów na drogach już nie. Każdy mający jakikolwiek dłuższy kontakt z Grekami, doskonale i szybko orientuje się, że pomimo swej witalności i gościnności, obywatele tego kraju rzadko bywają słowni, punktualni i dokładni w pracy. Aspekt ten również - o co zapewne będzie najtrudniej u lubiących unosić się honorem Greków - wymagałby głębokich przemyśleń, przewartościowań i pilnych zmian. Powszechne w tym kraju społeczne przyzwolenie dla korupcji, oszustw, cwaniactwa i układów rodzinnych musi zostać poprzez odpowiednią politykę społeczno-gospodarczą ,, wypalone żelazem”. Kryzys, jaki obecnie obserwujemy w Grecji, jest wynikiem

Wykres 4. Gospodarka Grecji - wybrane wskaźniki

Deficyt finansów publicznych w proc. PKB

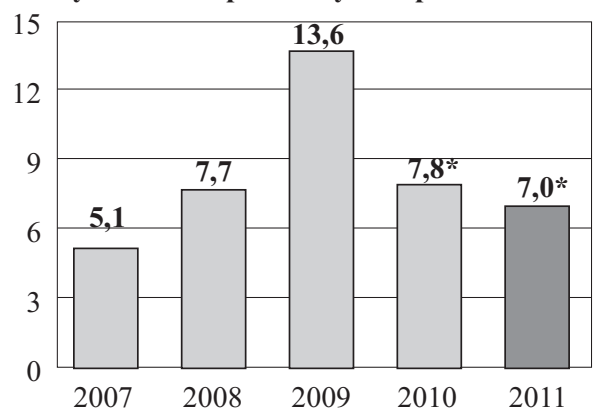

Udzial w PKB w 2009 r., w proc.

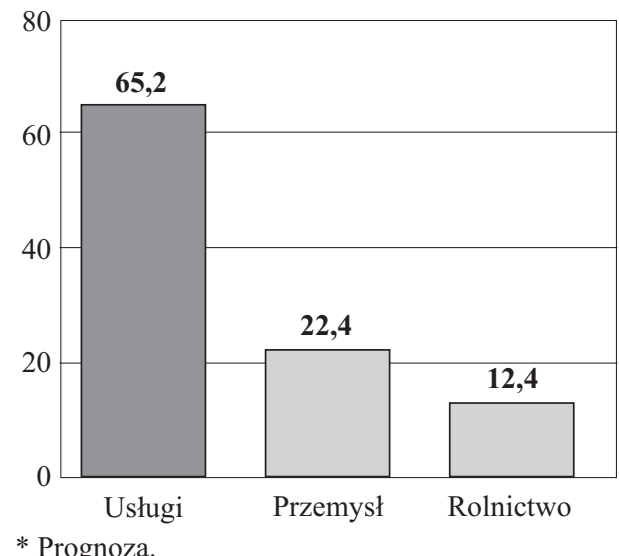

PKB, zmiana w proc.

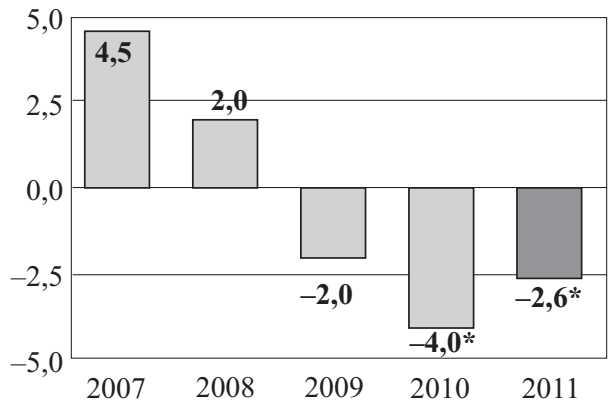

Dynamika PKB, w proc.

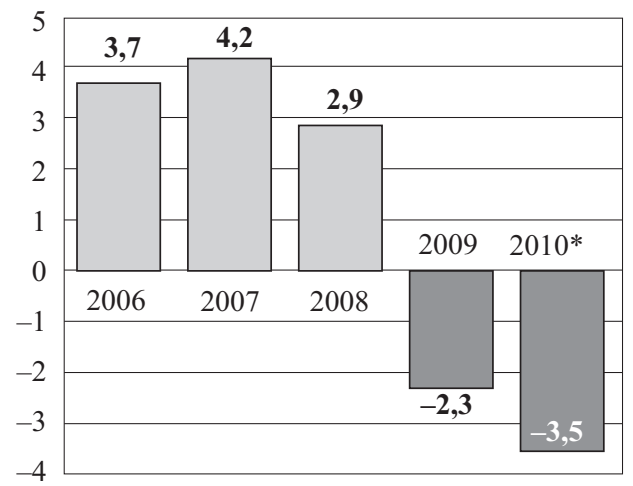

Źródło: Dane Eurostatu i MFW zawarte w „Rzeczpospolita”, 5 października 2010 r. 
wielu lat zaniedbań i błędów klasy politycznej (zarówno z socjalistycznego PASOK-u jak i konserwatywno-liberalnej Nowej Demokracji), ale także i instytucji unijnych niepotrafiących należycie i w odpowiednim czasie nadzorować i karać za kardynalne błędy w polityce gospodarczej. Grekom obecnie nie pozostaje więc nic innego jak efektywnie i szybko, przy wsparciu finansowym UE/MFW/EBC, wdrażać niezbędne reformy i ... modlić się aby nikt w Europie, a szczególnie Niemcy i Francja zniechęcone potencjalnym brakiem postępów nie wpadły na pomysł pozbycia się ,zbędnego balastu”, niweczącego wieloletnie procesy integracyjne w Europie, politycznie inicjując procedurę opuszczenia przez Grecję strefy euro. We wrześniu 2011 roku Komisja Europejska wykluczyła co prawda możliwość opuszczenia przez Grecję „euro area”, ale poziom zaufania inwestorów w świecie co do skuteczności wdrażania reform w tym kraju nadal jest bardzo niski, a groźba całkowitego i ostatecznego bankructwa (a nie 25 czy 75 procentowej niewypłacalności, jak prognozowały w różnym czasie międzynarodowe instytucje finansowe) bardzo wysoka.

\section{Irlandia}

Aktualnie najbardziej palącym problemem Irlandii nazywanej w światowej prasie i literaturze jeszcze do początków kryzysu w 2007 roku „celtyckim tygrysem” jest rosnący koszt pożyczania pieniędzy (czyli wzrost oprocentowania irlandzkich obligacji), z których finansuje ona deficyt budżetowy. Wiosną 2010 podobny scenariusz niemal doprowadził Grecję do „kontrolowanego bankructwa” (restrukturyzacji długu). W niemal ostatniej chwili została ona uratowana przez pożyczki z państw strefy euro i MFW.

Irlandię wpędziła w kłopoty tzw. spekulacyjna bańka na rynku nieruchomości, która na dobre pękła podczas pierwszej fali światowego kryzysu finansowego zrodzonego w USA. Nie była to jednak jedyna przyczyna kłopotów ,zielonej wyspy”. Irlandzki PKB skurczył się w latach 2007-2010 aż o 17 procent. Wskutek cięć budżetowych rządu premiera Briana Cowena pensje w sferze budżetowej spadły w ostatnich dwóch latach o blisko 20 procent, ale pomimo tego rząd zapowiada ograniczenie wydatków budżetowych na 2011 rok o kolejne 6 mld euro (3,8 proc. PKB) i następne 9 mld euro w latach 2012-2014. Oszczędności poprawią bilans budżetu, ale spowalniają rozwój gospodarczy i przyczynią się do wzrostu bezrobocia (obecnie i tak wysokiego - 13,7 procent). Irlandia posiada system podatkowy niezwykle przyjazny inwestorom - zaledwie 12,5-procentowy CIT (średni poziom CIT w UE-15 to aż 31,4 proc.). Efektywnie przyciagał on przez lata kapitał zagraniczny, głównie amerykański. Jednocześnie władze i instytucje finansowe tego kraju wręcz zachęcały do kupowania nowych posiadłości. Do tej pory ekonomiści i analitycy nie mogą się nadziwić, jak społeczeństwo państwa, w którym jest około 1,5 mln gospodarstw domowych, może posiadać ponad ... 600 tysięcy domów wakacyjnych. Przez całe lata Komisja Europejska chwaliła Irlandię za dobre wykorzystanie funduszy europejskich, ale ignorowała jej ewidentne nieprawidłowości rozwojowe. Nikt w Europie nie był bowiem przygotowany na tak nagłe pęknięcie bańki spekulacyjnej i spadek cen nieruchomości o 50-60 proc. (w latach 1997-2004 ceny nieruchomości w Irlandii wzrosły aż o 160 proc.). Budowa willi i apartamentów była najczęściej finansowana przez deweloperów, którzy zadłużyli się w irlandzkich bankach (głównie w Allied Irish Bank, Bank of Ireland i Anglo Irish Bank). Zła polityka kredytowa banków spowodowała, że znalazły się one na skraju bankructwa i uratować je mogło tylko państwo. Koszt tej pomocy szacowany był na co najmniej 50 mld euro. Dodatkowym problemem była struktura zobowiązań irlandzkich banków. Potrzeba finansowania rosnących cen nieruchomości, 
sprawiła, że w 2008 roku z Irlandii pochodziło zaledwie 22 proc. środków. Ponad 37 proc. kapitału banków irlandzkich pochodziło z depozytów i papierów wartościowych międzynarodowych rynków kapitałowych. Pożyczki dla niefinansowego sektora prywatnego wzrosły w 2008 roku do 200 proc. irlandzkiego PKB, przy średniej unijnej na poziomie około 100 proc. Irlandczycy swym bankom pomogli, ale zapłacili za to gigantycznym deficytem budżetowym. Międzynarodowy Fundusz Walutowy określa dzisiaj sytuację w Irlandii jako najgłębszq recesję $w$ kraju rozwiniętym ${ }^{12}$. Coraz częściej słychać też opinie, że to zbytnie uzależnienie od kapitału zagranicznego (głównie amerykańskiego) oraz polityka głównie skupiona na przyciąganiu nowych inwestorów, a nie promocji sektora krajowego były poważnym źródłem bieżących problemów ,zielonej wyspy”. Po zawrotnym wzroście gospodarczym w drugiej połowie lat 90. minionego wieku, w pierwszej połowie dekady 2000-2010 Irlandia rozwijała się wolniej, ale wciąż na dobrym, stabilnym poziomie 5,4 proc. średnio rocznie. Sytuacja diametralnie zmieniła się w połowie 2007 roku wraz wybuchem globalnego kryzysu gospodarczego i finansowego, mającego swoje epicentrum właśnie w Stanach Zjednoczonych. Trudno, aby problemy pogrążonej w recesji gospodarki amerykańskiej nie przełożyły się na malejąca aktywność inwestycyjną ich inwestorów w świecie, w tym także w Irlandii. W wyniku kryzysu PKB obniżył się z poziomu 162 mld euro w 2007 roku do poziomu 131 mld euro w 2009 roku (o 19 proc. w ciągu zaledwie dwóch lat!). Dług publiczny zwiększył się z 30 do 75 mld euro, a bezrobocie z 4-5 proc. do niemal 14 proc. (w sektorze budowlanym do 2010 roku pracę straciło niemal 30 proc. robotników). Irlandia, jedna z najbardziej zglobalizowanych gospodarek w świecie, na nowo stała się krajem emigrantów zarobkowych. Rosnące koszty pracy i w ogóle malejąca konkurencyjność gospodarcza spowodowały, że bardziej mobilny kapitał zaczął się z Irlandii delokalizować w kierunku ,wschodzących rynków" z Europy Środkowej i Wschodniej ${ }^{13}$.

\section{Wykres 5. Wskaźniki deficytu budżetowego i długu publicznego w wybranych państwach członkowskich UE}

Najbardziej zadłużone kraje UE, deficyt budżetowy i dług publiczny w 2009 r. w proc. PKB

\section{Deficyt budżetowy}

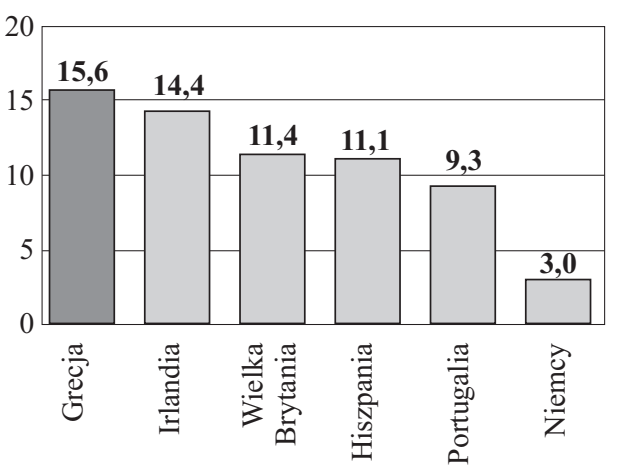

Dług publiczny

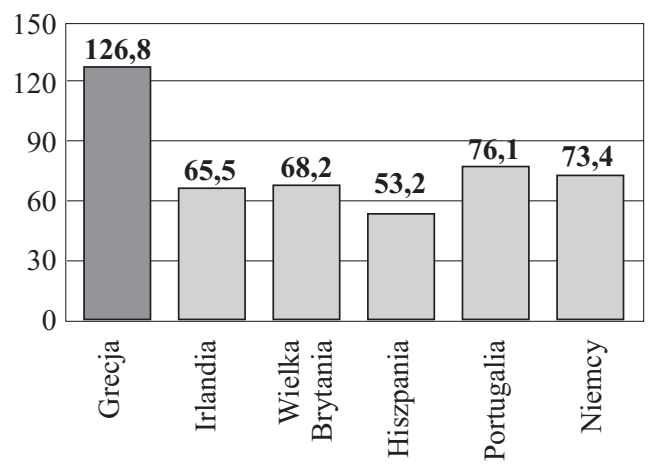

Źródło: Dane Eurostatu.

${ }^{12}$ E. Molendowski, M. Żmuda, Narodziny i kłopoty „tygrysa celtyckiego” - problemy wzrostu gospodarczego opartego na wzroście, ,Wspólnoty Europejskie” Biul. Inform. IKiCH, Warszawa 2010, nr 6 oraz D. Walewska, Wielki kryzys po wielkim boomie, „Rzeczpospolita”, 16 listopada 2010 r.

${ }^{13}$ Ibidem. 
Niepokój w Irlandii wzrósł też wskutek postanowień szczytu UE, na którym Niemcy przy wsparciu Francji zaczęły forsować zmiany w Traktacie lizbońskim pozwalające na „,kontrolowane bankructwo" państw strefy euro. Podczas restrukturyzacji długów bankruta jego pożyczkodawcy musieliby się zgodzić, że otrzymają zwrot niecałych pożyczek i nie w obiecanym wcześniej czasie. Planowana zmiana w traktacie spowoduje, że biedniejsze państwa strefy euro nie będą więc mogły już tak łatwo pożyczać (a więc i inwestować), wspierając się prestiżem posiadania wspólnej waluty z Niemcami czy Francją, a te państwa nie będą już dłużej i w nieskończoność płacić za błędy innych. To świadome przywrócenie elementu ryzyka na rynkach finansowych. Inwestorzy będq wiedzieć, że nie powtórzy się przypadek Grecji, kiedy inne kraje wzięty na swe barki całość odpowiedzialności za jej długi-zauważył ceniony ekonomista Andre Sapir z brukselskiego think tanku Bruegel ${ }^{14}$.

W listopadzie 2010 roku w Brukseli zebrali się ministrowie finansów strefy euro, czyli tzw. eurogrupa. Głównym tematem obrad była pomoc finansowa dla Irlandii borykającej się w 2010 roku z gigantycznym deficytem budżetowym rzędu 32 procent PKB (np. w Niemczech na koniec 2009 roku było to około 3 procent, a w Polsce - nieco ponad 7 procent). Irlandzki deficyt finansów publicznych - głównie wskutek pomocy dla banków udzielonej przez państwo - osiagnął w 2010 roku wymienione 32 procent PKB. Tak poważny niedobór w finansach państwa wymagać będzie od rządu w Dublinie ostrych cięć fiskalnych. Rząd zapowiedział, że oszczędności budżetowe sięgną w ciągu czterech lat $15 \mathrm{mld}$ euro, tak aby deficyt spadł w 2014 roku do 3 procent PKB. Konsolidacja fiskalna będzie jednak bardzo trudna - Irlandia wciąż bowiem stoi na krawędzi recesji ${ }^{15}$. Rynki finansowe wartość ewentualnej pożyczki dla Irlandii z EMSF szacowały na sumę 80-85 mld euro. Rząd irlandzki długo nie chciał wystąpić o pomoc, bojąc się, że ceną za wsparcie będzie nie tylko podwyżka podatku dla firm (CIT), który wynosi dziś tylko 12,5 procenta oraz wydatnie przyczyniał się do sukcesu gospodarczego tego ubogiego niegdyś kraju, ale i drastyczne cięcia finansowe i szybkie, niepopularne społecznie reformy ${ }^{16}$.

Irlandia nie ma problemów podobnych do Grecji czy Hiszpanii, które mają kłopoty z konkurencyjnością swej gospodarki i muszą szukać nowego modelu jej rozwoju. Nie nękająją też problemy, z jakim boryka się Portugalia, która przed obecną recesją nie mogła się pochwalić szybkim tempem wzrostu PKB. Irlandia miała jeden, ale za to bardzo poważny problem: bardzo zadłużone banki, wymagające znaczącej pomocy finansowej. Dopiero pod naciskiem Komisji Europejskiej, Irlandczycy zaakceptowali misję Międzynarodowego Funduszu Walutowego, Komisji Europejskiej oraz Europejskiego Banku Centralnego i ostatecznie przyjęli 85 mld euro wsparcia pochodzącego z Europejskiego Mechanizmu Stabilizacji Finansowej ${ }^{17}$. Ministrowie finansów UE w grudniu 2010 formalnie zatwierdzili obiecane miliardy pomocy dla Irlandii, a decyzja o pomocy dla Portugalii stała się już tylko kwestią czasu. Regularnie pojawiały się też obawy, że wkrótce po pomoc może wystąpić też Hiszpania (rosnąjej koszty pożyczania pieniędzy na rynkach finansowych), na co obecny fundusz stabilizacyjny raczej by już nie wystarczył. Stąd powstał pomysł jego znacznego zwiększenia (w części pochodzącej od państw strefy euro), choćby po to, aby pokazać światowym inwestorom, że państwa strefy solidarnie gotowe są ratować jedną z największych i najważniejszych gospodarek europejskich. Przeciwko temu pomysłowi ostro zaprotestowały jednak Niemcy, podob-

14 T. Bielecki, Irlandia w opałach, „Gazeta Wyborcza”, 16 listopada $2010 \mathrm{r}$.

${ }^{15}$ H. Kozieł, Wraca niepokój o Irlandię, „Rzeczpospolita”, 13-14 listopada 2010 r.

${ }^{16}$ A. Słojewska, Irlandia: damy sobie radę. Bruksela: i tak pomożemy, „Rzeczpospolita”, 16 listopada $2010 \mathrm{r}$.

${ }^{17}$ D. Walewska, Irlandczycy chcq ratować się sami, ,Rzeczpospolita”, 18 listopada 2010 r. 
nie zresztą jak wobec pomysłu emisji euroobligacji. Według analityków rynkowych mogłoby to zmniejszyć nacisk rynków na peryferyjne gospodarki strefy euro, ale też podwyższyć oprocentowanie niemieckich papierów dłużnych. Kolejny raz Niemcy musiałby więc wziąć na siebie dodatkowy ciężar przywracania równowagi budżetowej w innych państwach strefy, co spowodowałoby i tak bardzo zauważalny wzrost nastrojów eurosceptycznych w tym państwie i potencjalnie przegrane wybory partii rządzącej ${ }^{18}$.

Wykres 6. Gospodarka Irlandii - wybrane wskaźniki

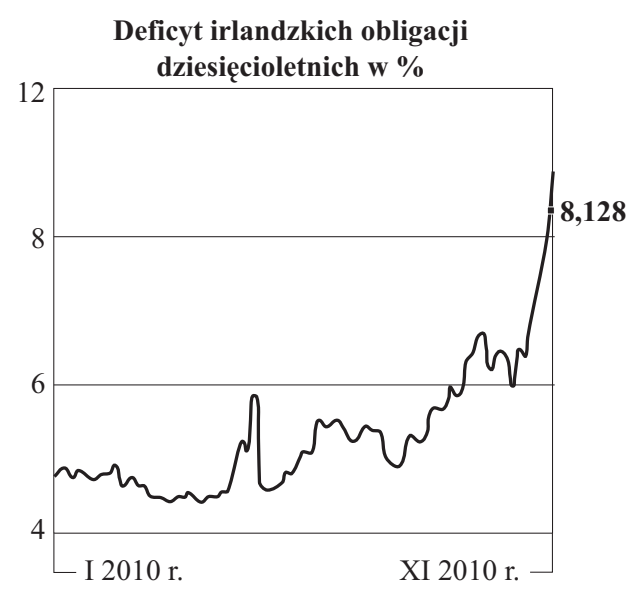

\section{Deficyt finansów publicznych Irlandii, w \% PKB}

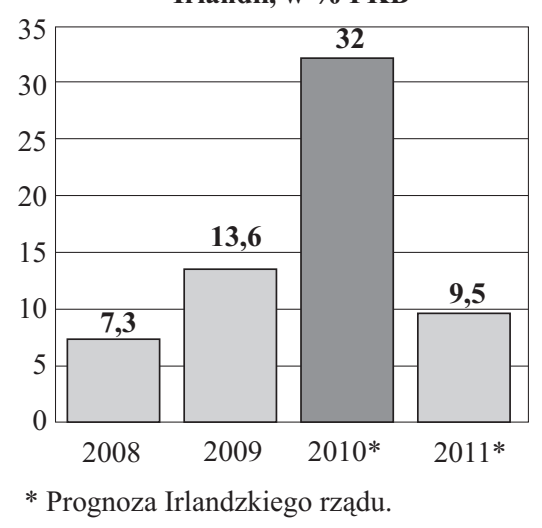

Rozwój gospodarki Irlandii, dynamika PKB w \%

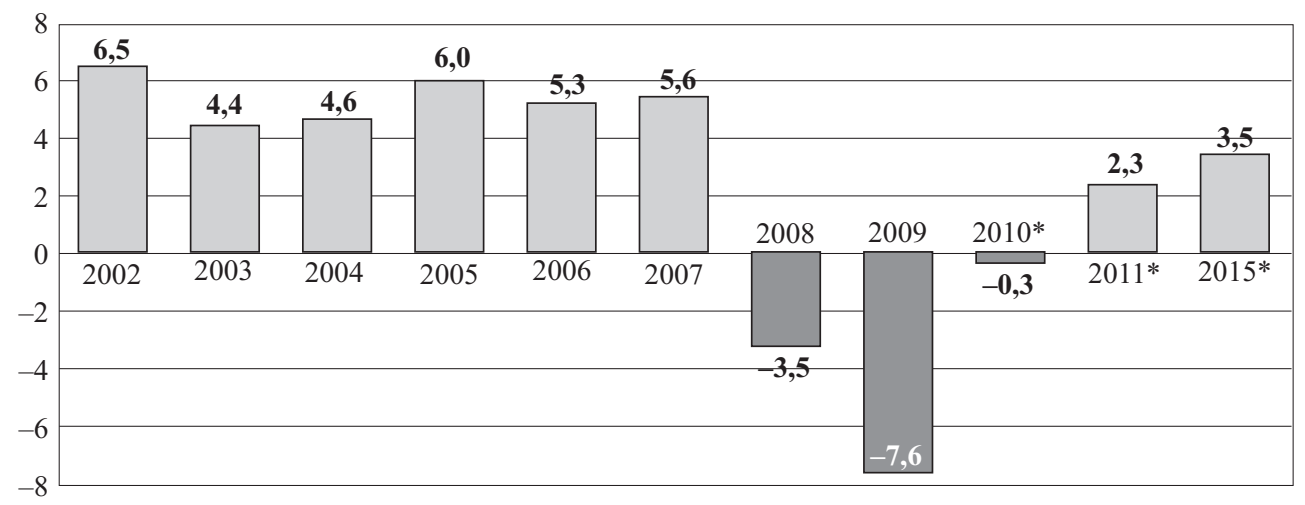

* Prognoza.

Źródło: Dane MFW, Bloomberg, Eurostat i rządu Irlandii.

Często porównuje się casus Irlandii do również objętej kryzysem bankowym Islandii. W 2009 roku żartowano, że różnica pomiędzy Irlandia oraz Islandia to jedna litera oraz pót roku w terminie bankructwa. Teraz nikt się z tego nie śmieje, a sytuacja Islandii wyglada nieco lepiej niż Irlandii - stwierdził Paul Krugman, amerykański noblista w dziedzinie ekono-

${ }^{18}$ T. Bielecki, Niemcy maja już dość ratowania, „Gazeta Wyborcza”, 7 grudnia 2010 r. 
mii, od pewnego czasu wieszczący upadek strefy euro. Według prognoz Komisji Europejskiej tempo wzrostu PKB będzie w obu krajach podobne, ale Islandia będzie mogła się pochwalić finansami publicznymi w znacznie lepszym stanie od irlandzkich. Stanie się tak bez znaczącego naruszenia skandynawskiego, opiekuńczego modelu polityki społecznej. Islandzki deficyt finansów publicznych wyniósł w 2010 roku 6,3 procenta PKB, irlandzki - 32 procent PKB. Komisja Europejska spodziewa się, że w przypadku Islandii deficyt zamieni się w 2012 roku w nadwyżkę, podczas gdy w Irlandii wyniesie około 9,1 procenta PKB. Dług publiczny Irlandii w ciągu nadchodzących lat może przekroczyć 120 procent $\mathrm{PKB}$, islandzki spadnie (według prognoz Międzynarodowego Funduszu Walutowego) do 80 proc PKB w 2015 roku. Analogia dotyczy też rynku pracy. OECD spodziewa się, że bezrobocie sięgnie w Islandii w 2011 roku 8,1 procenta, podczas gdy w Irlandii wyniesie 13,6 procenta.

Oba państwa przed kryzysem rozwijały się w podobnym tempie. Gospodarki obydwu zostały pogrążone przez kłopoty w krajowej bankowości. Zdaniem części ekonomistów, krytycznie nastawionych do sensowności utrzymywania wspólnej waluty, powodem, dla którego Islandia podnosi się z kryzysu szybciej, jest to, że w odróżnieniu od Irlandii pozwoliła upaść zadłużonym bankom oraz zdewaluowała koronę. Jej narodowa waluta straciła od września 2008 roku blisko 30 procent wobec USD, co spowodowało odczuwalne podrożenie kosztów życia obywateli, ale i ewidentnie poprawiło konkurencyjność eksportu. Irlandia nie mogła sobie pozwolić na dewaluację, bowiem należy do strefy euro i podporządkowana jest decyzjom EBC. Rosnący koszt ratowania banków z kolei niemal zrujnował finanse publiczne ,,zielonej wyspy" "19. Zwolennicy integracji monetarnej w Europie podkreślają z kolei, że bycie poza strefą euro i tak nie zwalnia rządów z prowadzenia racjonalnej polityki finansowej, a ewentualne koszty ratowania swej zadłużonej gospodarki musiałyby już ponosić indywidualnie, bez korzystnych rozwiązań typu pakiety wsparcia EMSF/EMS.

\section{Portugalia/Włochy}

Kryzys w strefie euro może zatoczyć coraz szersze kręgi. Po Grecji i Irlandii, zdaniem analityków kolejna będzie Portugalia, a może także Hiszpania. Problemy przeżywa też gospodarka włoska. Niemcy i Francja, aby zapobiec rozprzestrzenianiu się kryzysu finansowego na całą Unię domagały się, aby także Portugalia wystąpiła o międzynarodową pomoc finansową z EMSF. Portugalia zmaga się bowiem z poważnymi problemami gospodarczymi od dawna. Analizując lata 1997-2010 łatwo zaobserwować można malejący wzrost PKB prowadzący ostatecznie do recesji, systematycznie pogarszające się saldo na rachunku obrotów bieżących i deficyt budżetowy na średnim poziomie 4,6 proc. $\mathrm{PKB}^{20}$.

Analitycy szacowali, że Portugalia potrzebować będzie co najmniej 60 mld euro pożyczek, po które rząd tego kraju długo nie chciał występować, bojąc się drastycznych cięć wydatków budżetowych i konfliktów politycznych ze związkami zawodowymi. Eksperci niemieccy i francuscy byli z kolei zaniepokojeni tym, że Portugalia wkrótce może nie być w stanie finansować swych długów racjonalnie oprocentowanymi kredytami. Koszty, jakimi rynki finansowe obciążają pożyczki udzielane Portugalii, wzrosły bowiem znacznie pod koniec 2010 roku. W styczniu 2011 roku Portugalia sprzedała jednak swoje obligacje czteroletnie

${ }^{19}$ H. Kozieł, Islandia lepiej niż Irlandia, „Rzeczpospolita”, 13 grudnia $2010 \mathrm{r}$.

${ }^{20}$ Portugal's economy. Still scary (Briefing The euro area's debt crisis), ,The Economist”, January $15^{\text {th }} 2011$. 


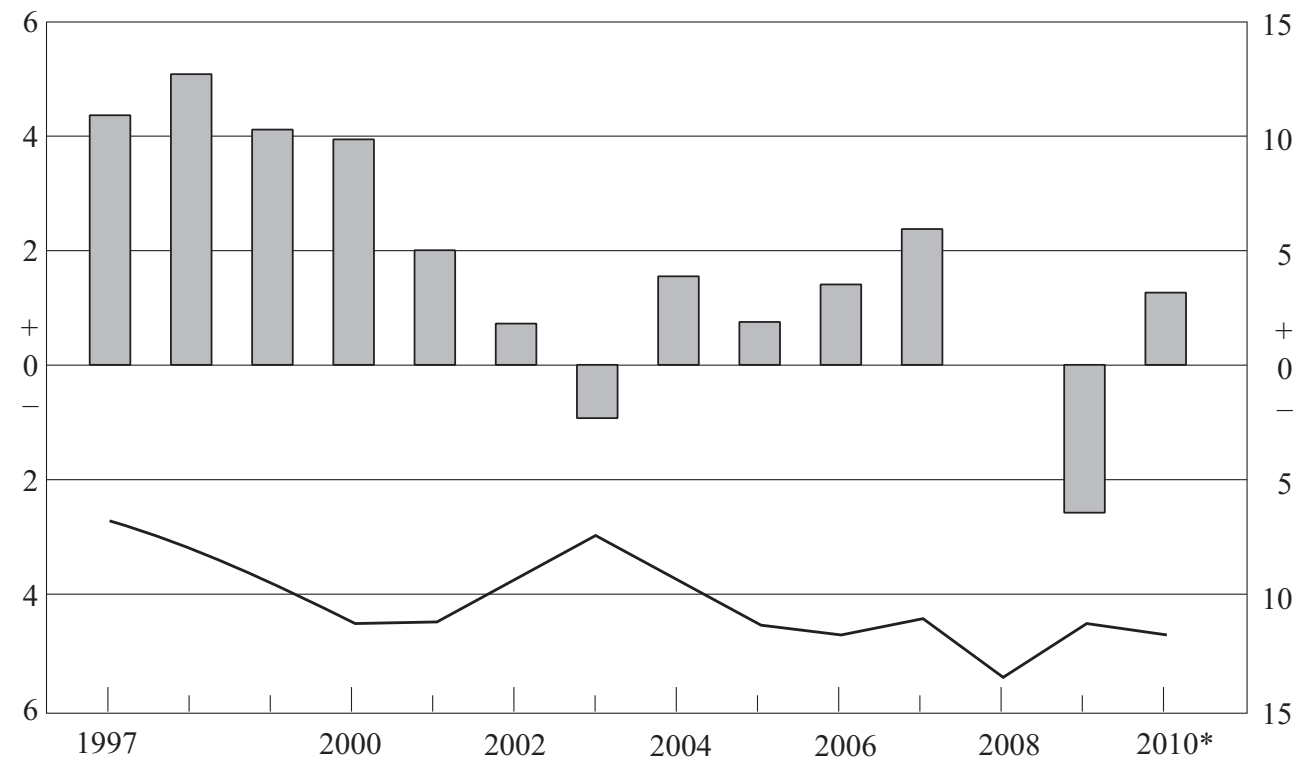

* Szacunkowo.

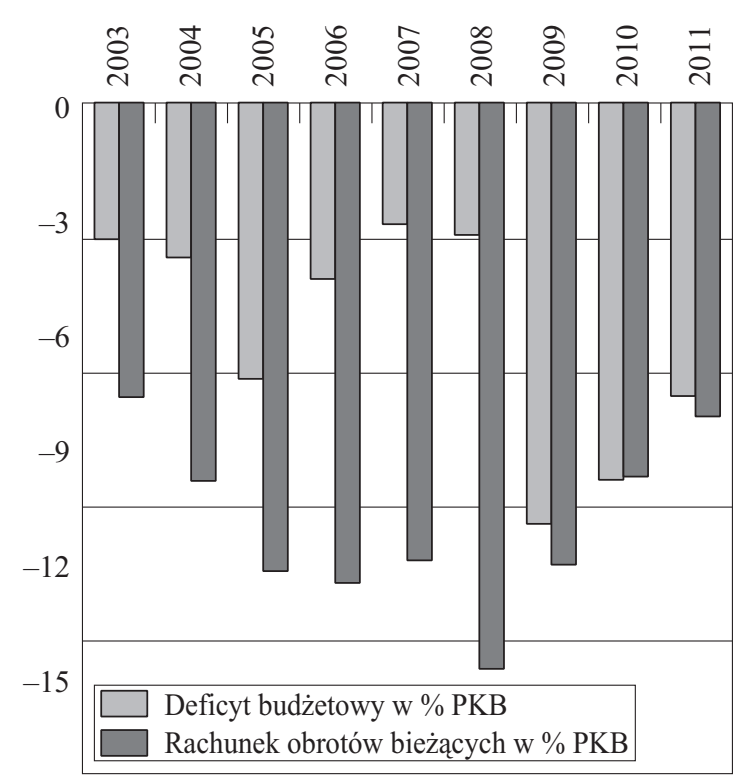

Wzrost PKB: 1,0\%

PKB: 211 mld USD

(PPP: 256 mld USD)

Inflacja: $0,8 \%$

Ludność: 10,7 mln

PKB per capita: 19810 USD

(PPP: 24060 USD)

Źródło: The world in figures: Countries: Portugal, „The Economist” Nov. $22^{\text {nd }} 2010$ from The World in 2011 print edition; Komisja Europejska, Haver Analytics - „The Economist”.

i dziesięcioletnie warte ogółem 1,249 mld euro. Rentowność papierów wyniosła 6,716 procenta, mniej niż oczekiwali eksperci. Rząd tego kraju planował wyemitować w 2011 roku 
papiery wartościowe na sumę około 20 mld euro. Udaną aukcję pięcioletnich obligacji na sumę 3 mld euro w tym samym czasie udało się przeprowadzić Hiszpanii. Rentowność papierów wyniosła 4,54 procenta, również mniej niż wynosiły prognozy analityków, a popyt przewyższał podaż ponad dwukrotnie ${ }^{21}$. W grudniu 2010 roku oprocentowanie włoskich dziesięcioletnich obligacji skarbowych sięgnęło niemal 4,7 procent, będąc o 2 pkt procentowe wyższe od niemieckich. Dla Włoch rosnący koszt zadłużania się - podobnie jak innych państw grupy PIIGS - stanowi poważny problem rozwojowy. W ciągu najbliższych trzech lat, aby refinansować swój dług publiczny (aż 1,7 bln euro!), Włochy będą musiały pożyczyć na światowych rynkach około 800 mld euro. Włoska gospodarka jest co prawda dużo bardziej zbilansowana od pozostałych państw grupy PIIGS (deficyt w stosunku do PKB jest niższy niż w Portugalii czy Irlandii, a sektor bankowy zdrowy), ale ogromnym problemem pozostaje jeden z największych w Unii dług publiczny (bardziej wewnętrzny niż zagraniczny, co jest akurat zaletą przy tak niestabilnej sytuacji na światowych rynkach finansowych i licznych atakach funduszy spekulacyjnych) ${ }^{22}$. W styczniu 2011 roku Włochy jednak bez większych problemów sprzedały pięcio- i piętnastoletnie obligacje o wartości 6 mld euro i rentowności tych pierwszych na poziomie 3,67 procenta. Przynajmniej czasowo świadczyło to o relatywnie wysokim zaufaniu inwestorów do stanu tej gospodarki i oddalało konieczność sięgnięcia po pomoc z EMSF (który w takiej sytuacji musiałby zostać - co już się sygnalizuje - znacznie powiększony). Widmo rozlania się kryzysu na Portugalię i Włochy przynajmniej czasowo się więc oddaliło.

\section{Hiszpania}

Bieżąca sytuacja ekonomiczno-społeczna w Hiszpanii w dużym skrócie wygląda następująco: młodzi ludzie chca pracy, światowe rynki reform a obywatele nowego rzadu. Rząd Jose Luisa Zapatero przez dwa lata zaprzeczał, że sytuacja finansowa kraju jest zła. Dopiero recesja gospodarcza i galopujące bezrobocie zmusiło jego gabinet do ogłoszenia spóźnionego programu bardzo niepopularnych społecznie reform, których głównym celem jest zredukowanie narastającego deficytu budżetowego z poziomu 11,1 procent $\mathrm{w} 2009$ roku do 4,4 procent na koniec 2011 roku. Jednym z jego elementów jest też wydłużenie (z małymi wyjątkami) czasu pracy do 67 roku życia. Największymi krytykami rządu socjalistów są studenci i w ogóle rzesze młodych Hiszpanów pozostających od lat bez stałego zatrudnienia lub bez pracy w ogóle. Na bardzo wysokie wskaźniki bezrobocia w Hiszpanii duży wpływ (analogia do Irlandii) miało pęknięcie bańki spekulacyjnej na rynku nieruchomości (spadek cen na rynku o 131 proc. w porównaniu ze szczytem sprzed kryzysu). W przemyśle budowlanym w czasach prosperity zatrudnionych było aż 13 procent Hiszpanów. Wydaje się, że tylko nowa ekipa rządząca i zdecydowanie bardziej restrykcyjny program oszczędnościowy może stworzyć tej gospodarce iberyjskiej szanse na powrót na prawidłową ścieżkę rozwoju. Plan minister go-

${ }^{21}$ Europe's debt crisis. Portugal prepares for a bail-out, „The Economist”, Apr $7^{\text {th }} 2011$ oraz Dobre wyniki aukcji długu w Hiszpanii i we Włoszech, „Rzeczpospolita”, 14 stycznia 2011 r.; Dobra aukcja portugalskich obligacji, gorzej z polskimi, „Rzeczpospolita”, 13 stycznia 2011 r.; A. Stefańska, pap, Portugalia idzie w ślady Grecji i Irlandii?, „Rzeczpospolita”, 10 stycznia 2011 r.; A. Słojewska, Portugalia na razie nie chce pomocy, „Rzeczpospolita”, 25 marca 2011 r. oraz T. Bielecki, Europa naciska na Portugalie,, „Gazeta Wyborcza”, 11 stycznia 2011 r.

${ }^{22}$ L. Baj, Włosi będa w opałach?, „Gazeta Wyborcza”, 2 grudnia 2010 r. Zobacz również: Europe's debt crisis. Surely this will solve the problem, ,The Economist”, May $4^{\text {th }} 2011$. 
spodarki i finansów Eleny Salgado Mendez zakłada wzrost PKB w 2011 roku zaledwie o 0,6 proc. i 1,1 proc. w 2012 roku i problemu wysokiego, strukturalnego bezrobocia na pewno w Hiszpanii nie rozwiąże $\mathrm{e}^{23}$.

Wykres 8. Wskaźniki dlugu publicznego w grupie PIIGS w latach 2000-2012 (prognoza)

Zadtużenie publiczne brutto

$w \% P K B$

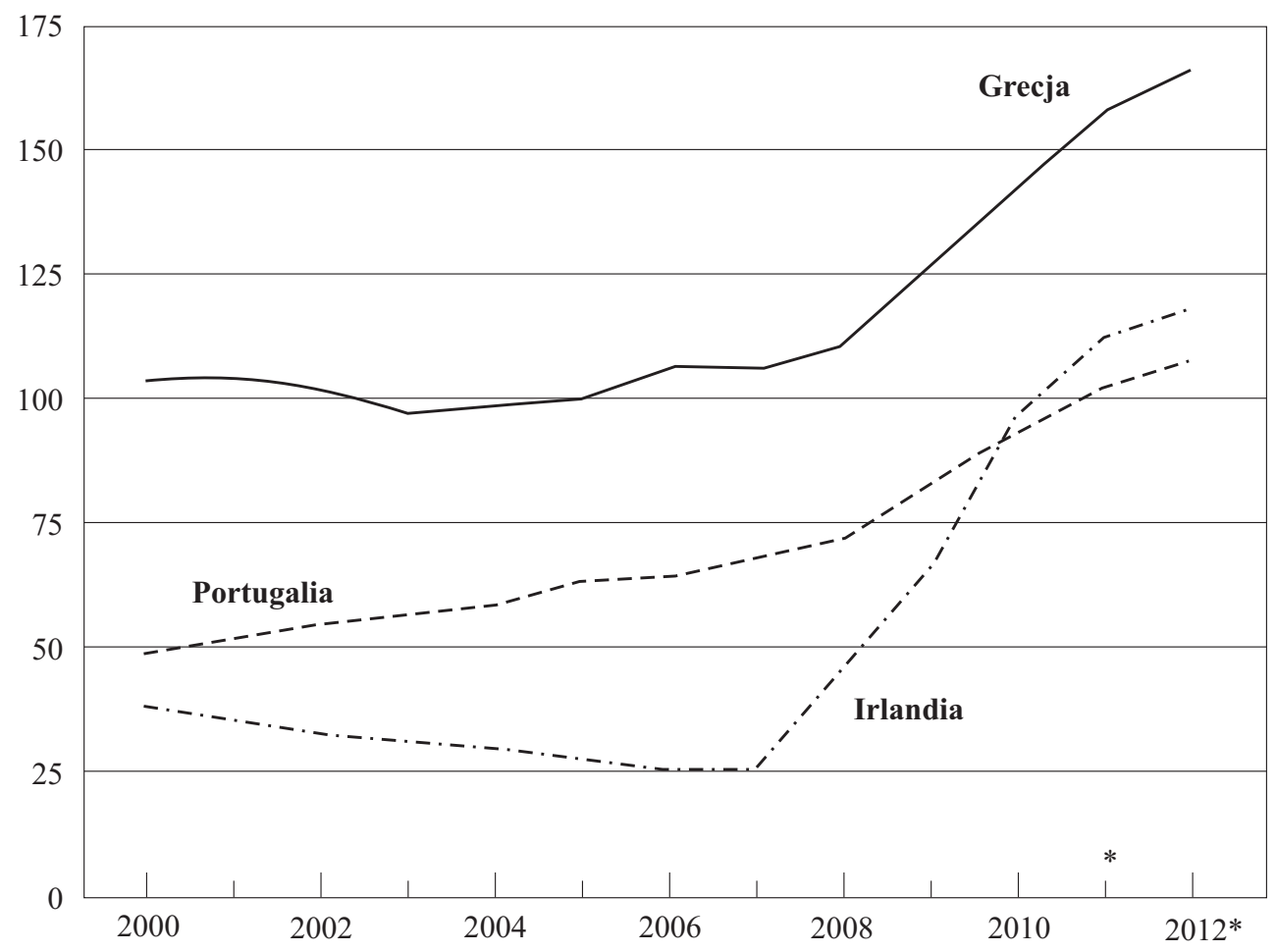

* Prognoza.

Źródlo: Komisja Europejska, Eurostat. Dane za „The Economist”.

We wrześniu 2010 roku Komisja Europejska przyjęła pakiet ustawodawczy zawierający najbardziej kompleksowe środki wzmocnienia zarządzania gospodarczego w UE i w strefie euro od czasu utworzenia unii gospodarczej i walutowej. Środki te zmierzają do poszerzenia i wzmocnienia nadzoru nad polityką budżetową, jak również polityką makroekonomiczną i reformami strukturalnymi, co jest konsekwencją stwierdzonych braków istniejącego ustawodawstwa. Przewiduje się nowe mechanizmy egzekwowania w odniesieniu do uchybiających swoim obowiązkom państw członkowskich. Wszystkie te reformy są zgodne z obowiązującym Traktatem lizbońskim i powinny zagwarantować Unii Europejskiej oraz

${ }^{23}$ Spanish politics. The unhappy campers, „The Economist”, May $28^{\text {th }} 2011$; Spains economic outlook. Reforming Zapatero, „The Economist”, February $5^{\text {th }}$ 2011; Spain and the euro crisis. A great burden for Zapatero to bear (Europe), „The Economist”, January $22^{\text {nd }} 2011$. 
Wykres 9. Rachunek obrotów bieżących w relacji \% do PKB w grupie PIIGS w latach 2000-2010

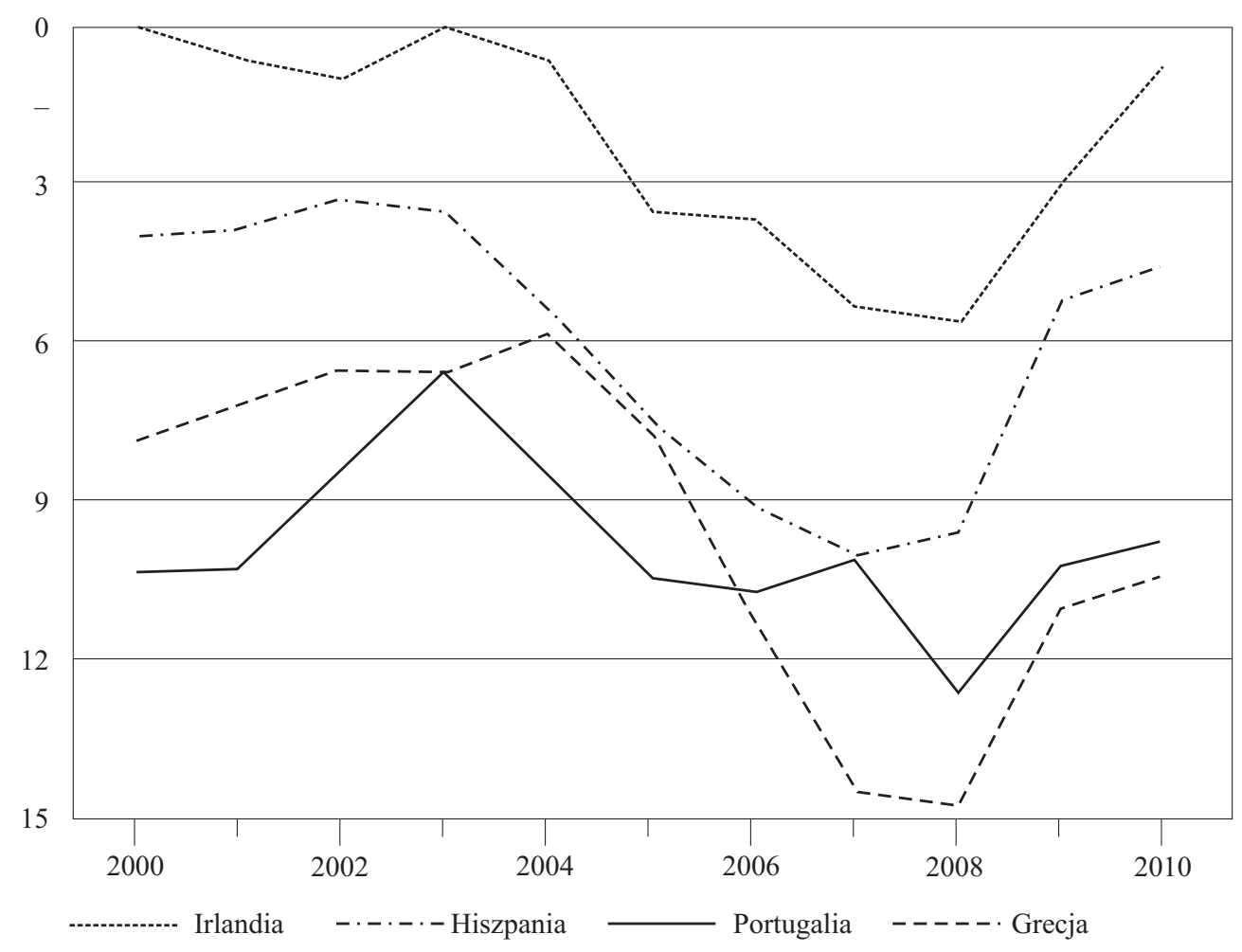

Źródło: Dane OECD za: „The Economist”.

strefie euro bardziej skuteczną koordynację polityki gospodarczej, a w konsekwencji szybszy i bardziej stabilny rozwój społeczno-ekonomiczny. W ten sposób Unia Europejska i strefa euro powinny dysponować wystarczającymi zdolnościami i siłą, aby prowadzić rozważną politykę gospodarcza, a co za tym idzie przyczyniać się do trwalszego wzrostu gospodarczego i zatrudnienia, zgodnie ze strategią zawartą w programie „Europa 2020”. Pakiet ustawodawczy składa się z sześciu aktów ustawodawczych (tzw. sześciopak): czterech wniosków dotyczących kwestii budżetowych, w tym szeroko zakrojonej reformy Paktu Stabilności i Wzrostu, oraz dwóch nowych rozporządzeń, których celem jest wykrywanie i skuteczne eliminowanie pojawiających się zaburzeń równowagi makroekonomicznej w Unii Europejskiej i strefie euro $^{24}$.

Po raz pierwszy od utworzenia unii monetarnej, Unia Europejska zaostrzy dyscyplinę budżetową. Pod koniec 2010 roku Komisja Europejska zaproponowała nowe sankcje dla państw strefy euro za nadmierny deficyt, dług publiczny i nierównowage gospodarczą. W całej UE wydatki publiczne nie powinny rosnąc szybciej niż PKB. Propozycje KE to efekt dyskusji, jaka rozgorzała w UE od czasu kryzysu greckiego, który zagroził stabilności euro. W celu zmuszenia członków strefy do większej dyscypliny budżetowej KE proponuje, by wprowa-

24 Zarzqdzanie gospodarcze w UE: Komisja przedstawia obszerny zestaw środków ustawodawczych, IP/10/1199, Bruksela, 29 września 2010 r. 
dzić nowe, niemal automatyczne sankcje dla niesubordynowanych państw strefy euro. KE będzie od nich żądać nieoprocentowanego karnego depozytu w wysokości 0,2 proc. PKB, który UE odmrażałaby po powrocie do właściwej polityki gospodarczej. W przeciwnym wypadku KE naliczy odsetki, a depozyt przepadnie i stanie się grzywną. Sankcje te nakładane mają być w procedurze ,, głosowania odwrotnego”. Oznacza to, że każdorazowo wniosek KE o nałożenie sankcji będzie uznawany za przyjęty, chyba że w ciągu 10 dni ministrowie finansów UE-27 odrzucą go kwalifikowaną większością głosów. Odsetki od depozytów oraz grzywny zostaną rozdzielone pomiędzy państwa strefy euro, do których sytuacji gospodarczo-budżetowej nie ma żadnych zastrzeżeń. Sankcje stanq się naturalnq konsekwencja, której moga spodziewać się uchybiajace swoim zobowiazaniom państwa członkowskie strefy euro - zapowiedziała KE.

W dyskusjach nad zacieśnieniem dyscypliny Polska opowiedziała się za równym traktowaniem wszystkich państw Unii, aby zapobiec pogłębianiu podziałów na strefę euro i państwa, które jeszcze nie przyjęły wspólnej waluty. Ale nowe sankcje obejmą na razie tylko strefę euro, bowiem prawnicy Komisji doszli do wniosku, że dla całej UE nie da się ich wprowadzić bez zmian traktatowych.

W celu zwiększenia dyscypliny finansowej w całej UE, niemiecki minister finansów Wolfgang Schauble w liście z 23 września 2010 roku do swych odpowiedników w UE zaapelował o jak najsurowsze i najszersze sankcje, w tym polegające na zamrażaniu subwencji unijnych (np. funduszy rolnych i strukturalnych) dla niesubordynowanych państw członkowskich. Nie było jednak zgody na takie rozwiązanie ze strony wszystkich ministrów UE-27 w ramach grupy „task force” pod kierunkiem Przewodniczącego Rady Europejskiej Hermana Van Rompuya, która dyskutowała, jak wzmocnić dyscyplinę budżetową i zarządzanie gospodarcze w UE. Chcąc jednak zmusić członków strefy euro do trzymania w ryzach wydatków publicznych, KE zaproponowała nową zasadę, by roczny wzrost wydatków publicznych nie przekraczat średniej stopy wzrostu PKB, chyba że rządy znajdą nowe dochody na pokrycie dodatkowych wydatków. Trzeba zerwać z obecna w przeszłości polityka samozadowolenia powszechna w czasie dobrej koniunktury. Część prewencyjna Paktu Stabilności i Wzrostu ma zapewnić, by państwa prowadzily rozważna politykę budżetowa w czasach dobrej koniunktury, tak aby móc dysponować odpowiednim buforem na czas pogorszenia warunków - argumentowała Komisja. Dlatego istniejąca procedura nadmiernego deficytu (powyżej 3 proc. PKB) będzie grozić także za nadmierny dług publiczny, przekraczający 60 proc. PKB. Ponadto KE zaproponowała nowy element unijnych ram nadzoru gospodarczego: procedurę nadmiernego zaburzenia równowagi gospodarczej. Będzie ona obejmować regularnie prowadzoną ocenę ryzyka zaburzeń równowagi finansowej, opierającą się na zestawie wskaźników takich jak saldo handlowe, koszt siły roboczej, dynamika cen nieruchomości, dług publiczny w stosunku do PKB itp. Jeśli KE uzna, że jest ryzyko funkcjonowania unii gospodarczo-walutowej, Rada UE ma przyjmować zalecenia i wszczynać procedurę karną. Członkom strefy euro i w tym przypadku grożą sankcje: coroczna grzywna w wysokości 0,1 proc. $\mathrm{PKB}^{25}$.

Na początku 2011 roku, w ważnym, ale i trudnym dla Unii Europejskiej momencie rozwojowym pojawiło się roczne sprawozdanie gospodarcze, rozpoczynające pierwszy ,, europejski okres oceny". Stwierdzono w nim, że po dwóch trudnych latach ( 2009-2010) zintegrowana Europa powoli, ale jednak podnosi się z recesji. Ożywienie gospodarcze nasila się i nabiera tempa, mimo że rynki krajowe oraz sektor finansowy ciągle jeszcze wymagają skoordynowa-

\footnotetext{
${ }^{25}$ Ibidem oraz Ostry kurs polityki budżetowej KE, PAP/af, www.forbes.pl.
} 
nych działań naprawczych i reform. Jednocześnie Komisja zauważa, że kryzys obnażył główne słabe punkty europejskiej gospodarki i ujawnił nasilający się brak równowagi wewnętrznej - problemy wynikające z wad strukturalnych. Europa - paradoksalnie - musi wykorzystać kryzys, aby zainicjować głęboką transformację swojej struktury gospodarczej. W opinii Komisji, co prawda w porównaniu z innymi regionami świata (w domyśle głównie w porównaniu z USA) Europa względnie lepiej poradziła sobie z bieżącym kryzysem i zamortyzowała jego uderzenie, nadal jednak istnieje ryzyko, że tempo wychodzenia z globalnej zapaści ekonomicznej i finansowej ulegnie spowolnieniu. Kryzys „2008+” w dalszym stopniu pogłębił różnice w wydajności pracy w porównaniu ze Stanami Zjednoczonymi, szczególnie w sferze konkurencyjności cenowej i kosztowej. Znacznie szybciej niż UE tempo wzrostu odzyskują ,gospodarki wschodzące”, z grupą BRICS (Brazylia, Rosja, Indie, Chiny, RPA) na czele ${ }^{26}$.

Wyciagnięcie ostatecznych wniosków ze wstępnych danych liczbowych przedstawionych do połowy listopada 2011 r. przez państwa członkowskie Unii w ramach projektów krajowych programów reform (KPR) jest trudne. Można jednak wyodrębnić pewne ogólne trendy $\mathrm{w}$ ramach następujących, poniższych zagadnień.

\section{Zatrudnienie}

Analiza projektów KPR wykazuje, że państwa członkowskie przyjęły odpowiedzialność za realizację tego celu oraz że w znacznym stopniu zaczęły już przeciwdziałać istniejącym „wąskim gardłom” na rynku pracy. Założone cele wahają się od 62,9\% (w przypadku Malty) do $80 \%$ (w przypadku Szwecji). Gdyby wszystkie państwa osiągnęły zakładane cele krajowe do 2020 r. lub też osiagnęły przynajmniej minimum docelowego przedziału, średni unijny wskaźnik zatrudnienia dla państw, które określiły cele krajowe, wyniósłby 72,4\%. Gdyby wszystkie państwa członkowskie osiągnęły wartości maksymalne wskazanego docelowego przedziału, średni wskaźnik zatrudnienia w UE wyniósłby $72,8 \%$. Innymi słowy, w oparciu o aktualne cele w zakresie krajowych wskaźników zatrudnienia całej UE zabrakłoby 2,2-2,6 punktów procentowych do osiagnięcia docelowych $75 \%$.

\section{Badania i rozwój}

Cel określony w strategii „Europa 2020” zakłada, że warunki inwestycyjne dotyczące badań i rozwoju ulegną poprawie: docelowo poziom inwestycji publicznych i prywatnych ma osiagnąć 3\% PKB. Zestawienie wszystkich tymczasowych celów krajowych wskazuje, że

\footnotetext{
${ }^{26}$ Roczne sprawozdanie gospodarcze. Załacznik 1: Sprawozdanie z postęu prac dotyczacych strategii ,,Europa 2020”, Komisja Europejska, Bruksela, dnia 12.1.2011, KOM(2011) 11 wersja ostateczna. Rada Europejska w czerwcu 2010 r. wprowadziła pojęcie ,, europejskiego okresu oceny”, wiążące rozwój polityki makroekonomicznej oraz reformy strukturalne w ramach strategii „Europa 2020”. „Europejski okres oceny” stanowi przedział czasu w pierwszej połowie każdego roku, kiedy to porównuje się sprawozdania państw członkowskich składane w ramach „Paktu na rzecz stabilności i wzrostu” oraz strategii „Europa 2020”, a następnie przekazuje państwom członkowskim wytyczne i zalecenia poprzedzające zakończenie prac nad budżetami krajowymi. Taka praktyka poprawić ma wstępną koordynację polityki gospodarczej i nadzór nad nią w UE, oferując przy tym korzyści płynące z jednoczesnego posiadania wspólnego programu na poziomie Unii oraz podejmowania indywidualnie dostosowanych działań na poziomie krajowym. W pierwszym ,,europejskim okresie oceny” w rocznym sprawozdaniu gospodarczym przedstawiono przede wszystkim kluczowe informacje na temat działań, które państwa członkowskie powinny potraktować priorytetowo. Analiza stanowiąca podstawę tych informacji została przedstawiona w trzech sprawozdaniach towarzyszących. Badanie sytuacji makroekonomicznej oraz rynków pracy w całej Unii Europejskiej wykazało, że aby uniknąć spowolnienia wzrostu oraz utraty miejsc pracy (,scenariusz straconej dekady”), państwa członkowskie powinny podjąć działania już w 2011 i 2012 roku.
} 
zagregowany poziom inwestycji w badania i rozwój wyniesie $2,7-2,8 \%$ PKB, a więc poniżej zakładanego poziomu 3\% PKB.

\section{Działania w obszarze zmiany klimatu a polityka energetyczna}

Jeśli chodzi o efektywność energetyczną, analiza projektów KPR wykazuje, że na obecnym etapie państwa członkowskie przejęły niewielką odpowiedzialność za ten cel. Wstępna ocena dowodzi, że łączne wysiłki państw członkowskich są w znacznym stopniu niewystarczające (razem poniżej 10\%), aby osiągnąć do 2020 r. ogólny cel UE zakładający obniżenie zużycia energii o $20 \%$.

\section{Kształcenie i szkolenie}

W strategii „Europa 2020” w odniesieniu do kształcenia określono dwa cele nadrzędne: do 2020 r. odsetek osób w wieku 18-24 lat przedwcześnie kończących naukę szkolną powinien być niższy niż 10\%; a co najmniej 40\% osób dorosłych z młodego pokolenia (30-34 lat) powinno mieć wykształcenie wyższe lub równoważne. Jeśli chodzi o przedwczesne zakończenie nauki, mimo iż niektóre państwa członkowskie ustaliły bardzo ambitne cele, ogólne wysiłki państw członkowskich prawdopodobnie nie będą wystarczające, aby do $2020 \mathrm{r}$. osiągnąc docelowy odsetek 10\%. Uwzględniając cele określone w projektach KPR, z wyłączeniem państw, które nie zdefiniowały jeszcze swoich celów, do 2020 r. odsetek osób przedwcześnie kończących naukę szkolną osiągnąłby 10,5\%, a zatem wspólny cel europejski 10\% nie zostałby osiagnięty. W wartościach bezwzględnych oznacza to, że w 2020 r. dodatkowo około 200 tysięcy młodych ludzi przedwcześnie zakończyłoby naukę.

Podobnie obecne cele krajowe określające odsetek absolwentów szkolnictwa wyższego nie są wystarczające, aby do 2020 r. urzeczywistnić cel ogólny. Przy całkowitym odsetku 37,3\% osób dorosłych z młodego pokolenia z wykształceniem wyższym nie uda się osiagnąć do $2020 \mathrm{r}$. wspólnego celu europejskiego określonego na poziomie $40 \%$. W wartościach bezwzględnych oznacza to, że w 2020 r. liczba osób z wyższym wykształceniem w wieku 30-34 lat byłaby niższa o około 800000 niż w przypadku, gdyby osiąnnięto zakładany odsetek $40 \%$.

\section{Włączenie społeczne i walka z ubóstwem}

Kryzys gospodarczy doprowadził do dramatycznego wzrostu liczby osób żyjących poniżej progu ubóstwa lub zagrożonych ubóstwem. Odwrócenie tego trendu oraz zapewnienie jednoczesnego wzrostu i spójności społecznej jest jednym z kluczowych założeń strategii „Europa 2020". Cel nadrzędny UE zakłada ograniczenie liczby Europejczyków żyjących poniżej progu ubóstwa o $25 \%$, dzięki czemu przynajmniej $20 \mathrm{mln}$ osób wydobyłoby się z ubóstwa. Wstępna analiza wykazała, że w większości państw członkowskich ubóstwo względne stanowi nadal jeden z głównych problemów. Większość państw określiła w projektach KPR swoje cele krajowe, niemniej jednak nie osiągnęły one jeszcze ambitnego poziomu celu uzgodnionego przez Radę Europejską. Większość państw członkowskich posłużyła się trzema uzgodnionymi wskaźnikami definiującymi cel na poziomie UE, przyznając jednocześnie, że zaradzenie ubóstwu we wszystkich jego aspektach wymaga szeroko zakrojonych strategii ${ }^{27}$.

Przegląd tematyczny pokazuje, że w państwach członkowskich Unii Europejskiej istnieje ogólna świadomość konieczności pilnej konsolidacji budżetowej oraz potrzeby przywrócenia

\footnotetext{
${ }^{27}$ Roczne sprawozdanie gospodarcze. Załacznik 1: Sprawozdanie z postępu prac dotyczacych strategii ,Europa 2020”, Komisja Europejska, Bruksela, dnia 12.1.2011, KOM(2011) 11 wersja ostateczna.
} 
porządku w sektorze finansowym i bankowym. Znacznie mniej uwagi poświęcono natomiast określeniu reform niezbędnych do przywrócenia równowagi, pobudzenia wzrostu i tworzenia nowych miejsc pracy. Podobne wnioski nasuwają się w odniesieniu do tymczasowych celów krajowych, które dowodzą, że nie uda się zrealizować uzgodnionych celów nadrzędnych na poziomie Unii. Niemniej jednak wstępne dane z 2010 roku pokazują, że różnice nie są aż tak duże, aby w nadchodzących latach nie udało się ich zlikwidować za pomocą zdecydowanych i skoordynowanych działań. Powrót do dyscypliny budżetowej oraz stabilnej sytuacji makroekonomicznej, przy jednoczesnym przeprowadzeniu reform strukturalnych, będzie wątkiem przewodnim kolejnego „, europejskiego okresu oceny”. Jednak, aby tak się stało Unia Europejska pilnie potrzebuje też nowego, bardziej skutecznego systemu zarządzania, kontroli i nadzoru w strefie euro, zapobiegającego fałszowaniu statystyk (casus Grecji za czasów rządu Costasa Simitisa), bezkarnemu zadłużaniu się (Grecja, Włochy). System musi też bezwzględnie wymuszać dyscyplinę fiskalną (skuteczniejszą walkę z szarą sferą) oraz większy nadzór i kontrolę nad działalnością banków. Unia Europejska, w szczególności strefa euro, wymaga też znacznie ściślejszej koordynacji polityki gospodarczej swych członków, choćby drogą opiniowania przez ministrów finansów strefy budżetów innych państw (pomysł wzbudzający kontrowersje) czy powołania Europejskiego Funduszu Walutowego, z systemem wsparcia, ale i automatycznie nakładanych kar finansowych za łamanie kryteriów zbieżności finansowej z Maastricht (choćby drogą ograniczania wypłat $\mathrm{z}$ funduszy spójnościowych) ${ }^{28}$.

Dopiero zredefiniowana na nowo formuła współpracy gospodarczej w Europie, powiązana $\mathrm{z}$ bardziej racjonalną niż dotychczas polityką makroekonomiczną i finansową państw członkowskich Unii Europejskiej, stworzy szansę na przyspieszony wzrost gospodarczy, trwałe wyjście z kryzysu i długofalową realizację ambitnych programów typu „Europa 2020”. Zintegrowana Europa potrzebuje dziś nie tylko wspólnej waluty, ale przede wszystkim wspólnej, racjonalnej i skutecznej polityki finansowej. Przykład objętej głębokim kryzysem Grecji, której dwuletnie obligacje pod koniec kwietnia 2010 roku zyskały wśród światowych inwestorów status „śmieciowych” powinien być bardzo poważną przestrogą dla wszystkich państw Unii. Bieżący kryzys w strefie euro powinien stanowić też kanwę do poważnej europejskiej debaty na temat pewnego zredefiniowania kryteriów zbieżności finansowej (szczególnie dotyczących dopuszczalnego wskaźnika inflacji i kursów odchyleń waluty od parytetu centralnego w ERM 2, o co postulowali choćby L. Balcerowicz i J. Pisani-Ferry), a przede wszystkim w kwestii stworzenia zupełnie nowego i efektywnego mechanizmu dyscyplinowania fiskalnego państw strefy euro. Działania te w powiązaniu z realizacją wizji innowacyjnej gospodarki europejskiej (strategia „Europa 2020”), szybszą liberalizacją rynku usług i uelastycznieniem unijnego rynku pracy stwarzałyby szanse na trwałe wydobycie Unii Europejskiej z niezwykle głębokiego kryzysu, w którym obecnie tkwi. Ich brak oznaczałby nie tylko rozpad strefy euro, ale i najcięższy kryzys gospodarczy w powojennej historii Europy, naznaczony trwałą recesją i wysokim bezrobociem, z rozpadem Unii Europejskiej włącznie.

\footnotetext{
${ }^{28}$ Uwagę skupił też pomysł powołanie do życia tzw. rządu ekonomicznego, o co postulował Prezydent Francji N. Sarkozy. Poważnie rozważano nadto projekt zgłoszony przez ministra finansów Niemiec W. Schauble, polegający na powołaniu do życia Europejskiego Funduszu Walutowego (analogia do MFW), który poprzez pożyczki pozwalałby unikać ryzyka niewypłacalności państwom strefy i który finansowany byłby z kar nakładanych na państwa przekraczające dopuszczalne progi deficytów budżetowych i długów publicznych (pomysł ekonomistów D. Grossa i T. Mayera).Wstępnie pojawił się też postulat obligatoryjnego wpisania do konstytucji państw posługujących się euro 3-procentowego progu dopuszczalnego deficytu budżetowego i 60-procentowego progu długu publicznego.
} 


\section{Summary}

Europe in crisis: economic prospects of the European Union by 2020 in the context of developmental problems in the PIIGS group

In 2009 the European Union, and in particular the euro zone, slid into a stage of economic recession, on account of the spreading global financial crisis, referred to as '2008+.' Considerable developmental problems are being experienced by the group of countries referred to as PIIGS, particularly by Greece. Due to the tight developmental interdependencies in the European common market, the bankruptcy of Greece could cause a domino effect, i.e. the collapse of other Mediterranean economies, such as Spain or Italy, financial difficulties for Germany and France, and consequently a threat to integration processes throughout Europe. This paper is the first part of the analysis of this issue, where the author analyzes both the causes and effects of the present financial crisis in the euro zone, the first correctional activities undertaken by the EU institutions, and further developmental prospects of the European Union by 2020. 